\title{
Bitlis İlinin Balık Yetiştiriciliğindeki Mevcut Durumu ve Yetiştiricilik Potansiyelinin Belirlenmesi
}

\author{
İlbey DOĞAN ${ }^{1}$, Kenan KÖPRÜC $\ddot{U}^{2 *}$ \\ ${ }^{1}$ Çemişgezek Illçe Tarım ve Orman Müdürlügüu, Elazı̆̆, Türkiye \\ ${ }^{2}$ Fırat Üniversitesi Su Ürünleri Fakültesi, 23119 Elazığ, Türkiye \\ (ORCID: 0000-0002-4128-4449) (ORCID: 0000-0002-5697-5224)
}

\begin{abstract}
$\ddot{\mathbf{O} z}$
$\mathrm{Bu}$ çalışmada, Bitlis ilinin balık yetiştiriciliğindeki mevcut durumu ve su ürünleri yetiştiricilik potansiyelinin belirlenmesi amaçlandı. Mevcut işletmelerin ve su kaynaklarının tamamına yıl boyunca 3 aylık periyotlar halinde gidildi. İşletmelerdeki yetkili kişi ve çalışanlarla yüz yüze yapılan anket çalışmasıyla işletmelerin yapısal, biyolojik, teknik, sosyal ve ekonomik özellikleri hakkında veriler elde edildi. Ayrıca, su kaynaklarının bazı fiziksel (sıcaklık, debi ve bulanıklık) ve kimyasal (oksijen, pH ve nitrat) özellikleri tespit edildi. Elde edilen sonuçlara göre; işletmelerin \%20’si vadi arasında, \%40’1 dağ eteğindeki yamaçlarda ve \%40’1 ise açık arazide kurulmuştur. İşletmelerin \%80'inin üretimde kaynak suyunu kullandığ $1, \% 20$ 'sinin ise göl üzerinde üretim yaptığı belirlendi. Bitlis ilindeki işletmelerin yıllık üretim kapasiteleri 25-100 ton arasında değişmektedir. İşletmelerin il genelindeki toplam proje kapasitesi 211 ton/y1l, fiili kapasitesi 176 ton/y1l ve ortalama kapasite kullanım oranı ise $\% 74,21 \pm 35,46$ 'dır. Bu işletmelerin \%60'1 ihtiyaç duydukları yıllık 6250000 adet yavru balığı kendi kuluçkahanelerinde üretirken, \%40’’ ise ihtiyaç duyduğu yıllık 130000 adet yavru balığı dışarıdan satın almaktadır. Mevcut işletmelerin \%80'inin beton havuzlarda, \%20'sinin ise ağ kafeslerde balık üretimini yaptığ tespit edildi. Bitlis ilindeki işletmelere ait toplam fiili üretim; \%94,3 oranında beton havuzlarda, $\% 5,7$ oranında ise ağ kafeslerde gerçekleşmektedir. Bitlis ilindeki balık üretim tesisleri \%100 şahıs işletmesi olarak faaliyet göstermektedir. İşletmelerin \%20'sinin öz sermaye kullandıkları, \%80'inin de öz sermaye haricinde teşviklerden faydalanarak faaliyet gösterdiği tespit edildi. Bu ildeki mevcut işletme sahiplerinin \%60’1 44-52, \%40'1 ise 53-63 yaş aralığındadır. Bunların \%40’1 ilkokul, \%20'si ortaokul ve \%40’1 ise lise mezunudur. Mevcut işletmelerde toplam 20 kişi çalışmakta olup, bunların \%70'i ilköğretim, \%25'i lise ve \%5'i ise lisans mezunudur. Toplam personelin \%95'i erkek, \%5'i ise bayandır. İldeki potansiyel su kaynaklarının ortalama sıcaklık değerleri 9,51$14,42{ }^{\circ} \mathrm{C}$ arasında olup, debisi 6,75-426,3 L/sn, bulanıklığ 1 0,55-12,95 JTU, çözünmüş oksijeni 4,86-9,25 mg/L, pH's1 6,27-9,76 ppm ve nitrat düzeyi 0,00-14,70 mg/L aralığında değişmektedir. Sonuç olarak, Bitlis ilinde kültür balıkçılığının nitelik ve niceliğinin arttırılabilmesi, üretimin optimize edilebilmesi ve geleceğe yönelik projeksiyonların yapılabilmesi, su ürünleri üretiminin il, bölge ve ülke ekonomisine olan katkılarının arttırılabilmesi için; mevcut işletmeler yapısal, teknik ve ekonomik yönlerden geliştirilmelidir. Devlet desteğinin artması ve çeşitlilik kazanması, teknolojik gelişmeler ve potansiyel su kaynaklarının her geçen yıl balık üretiminde kullanılmasına paralel olarak su ürünleri yetiştiriciliğine olan ilginin artması beklenmektedir.
\end{abstract}

Anahtar Kelimeler: Bitlis, Balık Yetiştiriciliği, Mevcut Durum, Su Ürünleri Potansiyeli

\section{Current Situation of Fish Culture in Bitlis Province and Determination of Aquaculture Potential}

\begin{abstract}
In this study, the aim is to find out the current situation of fish culture along with the potential of aquaculture in Bitlis Province. All of the existing enterprises and water resources were used in 3-month periods throughout a year long proccess. In the face-to-face survey conducted with authorized people and employees in the enterprises; Data on the structural, biological, technical, social and economic characteristics of the enterprises were obtained. In addition, the water resources; some physical (temperature, flow rate and turbidity) and chemical (oxygen, $\mathrm{pH}$ and
\end{abstract}

*Sorumlu yazar: kkoprucu@firat.edu.tr
Geliş Tarihi: 28.06.2019, Kabul Tarihi: 25.09.2019 
nitrate) properties were determined. According to the obtained results; $20 \%$ of the enterprises are located in the valley, $40 \%$ in the slopes and $40 \%$ in the open land. Trout production is done in the total pool area of $6019 \mathrm{~m}^{2}$ in these enterprises. It was determined that $80 \%$ of the enterprises used spring water in production, and $20 \%$ of them used the water of the lake. The annual production capacity of the enterprises in Bitlis Province varies between 25100 tons. The total project capacity of the enterprises in the province is 211 tons/year, the actual capacity is 176 tons/year and the average capacity utilization rate is $74.21 \pm 35.46 \%$. When these enterprises are take into consideration individually, it was found out that $60 \%$ of them produce an annual average of 6250000 fry fish in their own hatcheries, while $40 \%$ buy an annual 130000 fry fish per year. It has been determined that $80 \%$ of the enterprises are in concrete ponds and $20 \%$ in fish cages. Total actual production in Bitlis Province is $94.3 \%$ in concrete ponds and $5.7 \%$ in network cages. Fish production enterprises in Bitlis Province operate as an $100 \%$ private enterprise. It was revealed that $20 \%$ of the enterprises use equity and $80 \%$ of them operate by using incentives other than equity. In this province, $60 \%$ of the existing owners are 44-52 and 40\% are between 53-63. The $40 \%$ of them are primary school, $20 \%$ are secondary school and $40 \%$ are high school graduates. A total of 20 people are employed in the existing enterprises, $70 \%$ of them are primary school, $25 \%$ are high school and 5\% are undergraduate. The $95 \%$ of the current staff are male and $5 \%$ is female. The average temperature of potential water resources in the province is between $9.51-14.42^{\circ} \mathrm{C}$ and the flow rate is $6.75-426.3 \mathrm{~L} / \mathrm{s}$, the turbidity is $0.55-12.95$ JTU, the dissolved oxygen is 4.86-9.25 $\mathrm{mg} / \mathrm{L}, \mathrm{pH}$ is $6.27-9.76 \mathrm{ppm}$ and nitrate level ranges between $0.00-14.70$ $\mathrm{mg} / \mathrm{L}$. In conclusion, the existing enterprises in Bitlis Province should be developed in the structural, technical and economic aspects, in order to increase the quality and quantity of aquaculture production, optimize the production, make projections for future, increase its contribution to the economy of the province, region and country. The interest in aquaculture is expected to increase in line with the increase in the state support, its diversity, technological developments and the use of potential water resources in fish production year by year.

Keywords: Bitlis Province, Fish Culture, Current Situation, Aquaculture Potential

\section{Giriş}

Dünya nüfusunun artmasıyla birlikte gıda ihtiyacı artmış ve buna bağlı olarak tüm dünyada su ürünleri yetiştiriciliği faaliyetleri ivme kazanmıştır. Sağlıklı beslenmedeki önemli rolünden dolayı, su ürünlerine olan ilgi de gün geçtikçe artmıştır. Avcılık yoluyla elde edilen su ürünlerinin sınırlı olması ve ihtiyacı karşılayamaması nedeniyle, su ürünleri yetiştiriciliği vazgeçilmez bir üretim modeli haline gelmiştir [1, 2]. Dünyada en hızlı gelişen gıda sektörü su ürünleri yetiştiriciliğidir [3]. Bu sektör önemli bir gida kaynağını sağlamanın yanısıra; yoğun istihdam oluşturması, endüstri alanında ham madde temininde yer alması ve değerli bir ihracat ürünü sunması bakımından da önemlidir [4].

Ülkemiz su ürünleri sektörü sürekli bir değişim ve gelişim içerisindedir. Yetiştiricilik yolu ile üretilen balık miktarı 2000 yılında 79.031 ton iken, bu miktar hızlı bir artış göstererek 2018 yılında 314.573 tona ulaşmış ve ülkemize kattığı değer 4.049.886.200 TL olmuştur. Toplam su ürünleri üretimimiz ise 628.631 tona ulaşmıştır. Mevcut üretimin \%35,3'ünü deniz balıkları, \%9,9'unu diğer deniz ürünleri, $\% 4,8$ 'ini iç su ürünleri ve $\% 50$ 'sini yetiştiricilik ürünleri oluşturmuştur. Yetiştiricilik yoluyla üretilen balıkların \%66,6'sı denizlerde ve \%33,4'ü ise iç sularda gerçekleşmiştir [5]. Önemli su kaynaklarına sahip olan ülkemizin üretim potansiyeli değerlendirildiğinde, fiili üretimin beklenen değerlere ulaşamadığı görülmektedir. Bu durum, diğer sektörlerde de karşımıza çıkabilen; altyapı yetersizliği, üretim planlamasının işlevsellikten uzak olması, finansman kaynaklarının doğru kullanılmaması ve pazar araştırmasının yeterince yapılmaması gibi nedenlere bağlanabilir. Mevcut sorunlar; doğru verilere ulaşılması ve bu verilerin gerçekçi, ön yargısız ve sağlıklı bir biçimde yorumlanması ile çözümlenebilir. Aksi taktirde, verimli ve nitelikli bir üretim yapısının oluşması mümkün değildir [6]. Türkiye birçok ülke ile kıyaslandığında su ürünleri yetiştiriciliğinde optimal şartlara sahip ekolojik ve limnolojik özellikleri olan ender ülkelerdendir. Bu avantajların üretimde etkin bir şekilde kullanılması durumunda su ürünlerinin ekonomiye olan katkısı artacaktır [7].

Ülke genelinde olduğu gibi Bitlis ilinde de çeşitli su kaynakları mevcuttur. Van, Nazik, Nemrut, Arin ve Aygır Gölleri'nin yanısıra; Garzan ve Bitlis çayları, Güzeldere, Ağkiz ve Oranz dereleri ile Karasu bu ilin başlıca akarsularını oluşturmaktadır. Bunun dışında çok sayıda irili ufaklı dere ve çaylar da bulunmaktadır [8]. Mevcut su kaynaklarından sulama, içme, balık avcılığ faydalanılmaktadır. Bitlis İl Tarım ve Orman Müdürlüğü’nün 2017 yılı kayıtlarına göre; Bitlis ili 176 ton alabalık yetiştiriciliğiyle ülke genelindeki alabalık üretiminde $\% 0,05$ 'lik bir paya 
sahiptir [9]. Bitlis ili zengin su kaynaklarına sahip olmasına rağmen, kültür balığı üretiminde arzu edilen seviyede değildir. Bu nedenle çalışmada, Bitlis ilinin balık yetiştiriciliğindeki mevcut durumu ve su ürünleri yetiştiricilik potansiyelinin belirlenmesi, güçlü ve zayıf yönlerinin ortaya konulması amaçlanmıştır.

\section{Materyal ve Metot}

Araştırmanın ana materyalini, Bitlis ilindeki gökkuşağ 1 alabalığı yetiştiriciliği yapan işletmeler ve potansiyel su kaynakları oluşturmaktadır. Bitlis İl Tarım ve Orman Müdürlüğü kayıtlarına göre; ilde aktif olarak üretim yapan toplam 5 adet işletme ve 37 adet su kaynağı bulunmaktadır (Şekil 1).

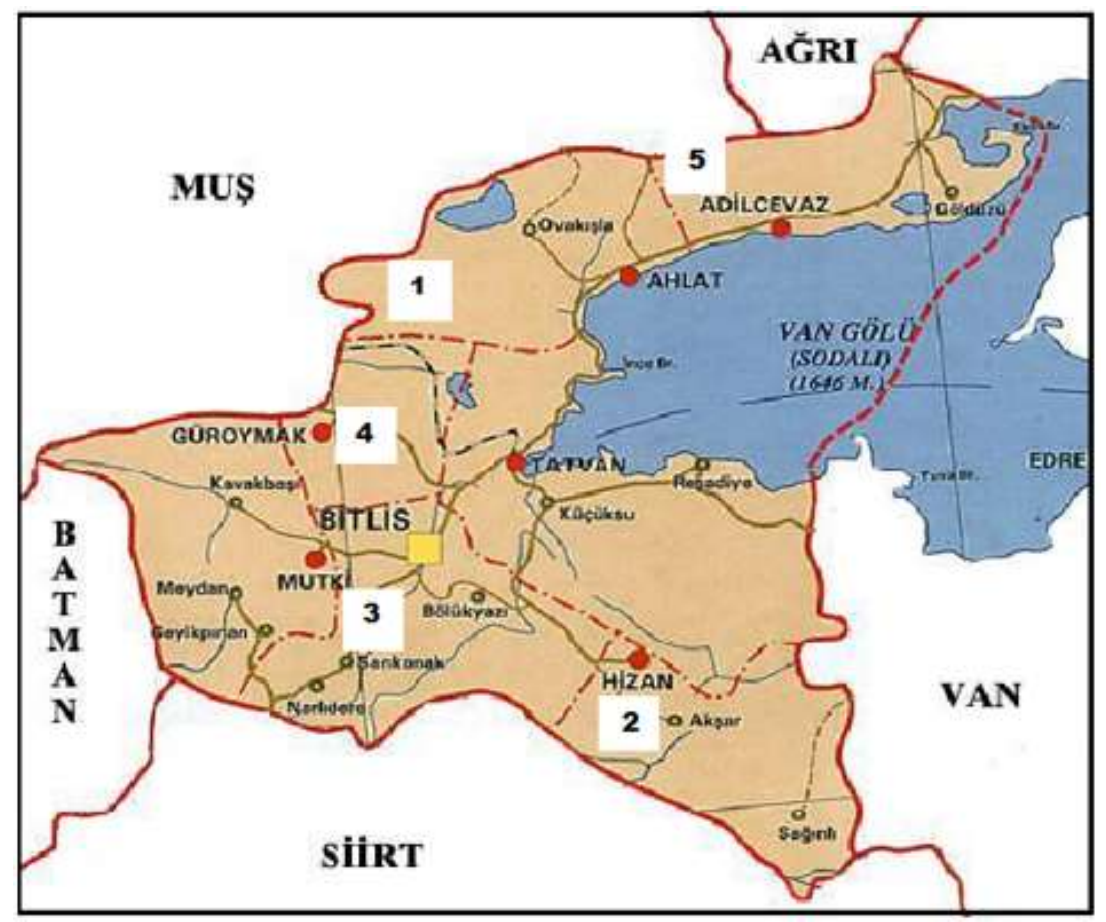

Şekil 1. Bitlis ilindeki gökkuşağı alabalığı üreten işletmelerin konumu (1-5) ve su kaynakları [10]

Çalışma, 1 Haziran 2017 ile 1 Haziran 2018 tarihleri arasında gerçekleştirilmiştir. İşletmelerin yapısal, biyolojik, teknik, sosyal ve ekonomik özelliklerinin belirlenmesine yönelik anket formu hazırlanmıştır [11-18]. Aktif olan işletmelerin ve mevcut su kaynaklarının tamamına yıl boyunca 3 aylık periyotlar halinde gidilmiştir. İşletmelerdeki yetkili kişi ve çalışanlarla yüz yüze yapılan anket çalışmasıyla veriler elde edilmiştir. Ayrıca, ildeki potansiyel su kaynaklarının bazı fiziksel (sıcaklık, debi, bulanıklık) ve kimyasal (oksijen, $\mathrm{pH}$, nitrat) özellikleri tespit edilerek, balık yetiştiriciliğine uygunluğu değerlendirilmiştir.

Su sıcaklığı termometre $\left(1{ }^{\circ} \mathrm{C}\right.$ taksimatlı), çözünmüş oksijen miktarı $(\mathrm{mg} / \mathrm{L})$ portatif bir oksijen metre, pH'sı portatif bir pH metre, bulanıklılık ise "Secchi disc" [19] kullanılarak ölçülmüş̧ür. Sudaki nitrat düzeyi spektrofotometrik yöntemle belirlenmiştir [20]. Su debisinin belirlenmesinde; yüzdürme ve enine kesit yöntemi ile su kaynağında $20 \mathrm{~m}$ uzunluğunda bir aralık belirlenmiş ve bu $20 \mathrm{~m}$ içerisindeki 5 ayrı noktadan en ve derinlik ölçüleri alınarak ortalama derinlik ve genişlik tespit edilmiştir. Ortalama $25 \mathrm{~cm}$ uzunluğunda ve $5 \mathrm{~cm}$ enindeki tahta parçası daha önce belirlenen $20 \mathrm{~m}$ uzunluğundaki alanın başlangıç noktasından bırakılarak toplam mesafeyi kaç saniyede tamamladığı ölçülmüş ve "En $x$ Boy $x$ Derinlik x 0,85/Zaman" formülü ile hesaplanmıştır [21]. Ayrıca, Bitlis İl Tarım ve Orman Müdürlüğü kayıtlarından yararlanılarak, mevcut verilerin güvenilirliği test edilmiştir.

İşletmelerin kapasite kullanım oranları, su kaynaklarının çözünmüş oksijen, pH, nitrat, sıcaklık, bulanıklılık ve debisine ait mevsimsel ölçüm değerleri arasındaki farkın önem derecesi $(0,05)$ "tek yönlü t testi” kullanılarak belirlenmiştir. Bu değerlere ait aritmetik ortalama ve standart sapma (Ss)'nın hesaplanması, belirtilen istatistiksel analizlerin yapılması işlemlerinde "SPSS 21.0 bilgisayar paket programı" kullanılmıştır. 


\section{Bulgular ve Tartışma}

\section{1. İşletmelerin kuruluş yeri, yılı, üretim durumu ve yerleşim merkezine uzaklığı}

Bitlis İl Tarım ve Orman Müdürlügüne kayıtlı olan ve aktif olarak entansif gökkuşağ 1 alabalığ1 yetiştiriciliği yapan 5 adet işletme mevcuttur. Bunların yerleşim merkezine uzaklıkları 10,1-98,1 km arasında değişmektedir (Tablo 1). Ayrıca, pasif olan 1 adet işletmenin çeşitli ekonomik problemlerden dolayı üretimini geçici olarak durdurduğu, yarı entansif sazan ve entansif karadeniz alabalığı yetiştiriciliği yapan toplam 2 adet işletmenin ise 2017 yılında faaliyetine son verdiği tespit edilmiştir.

Tablo 1. Bitlis ilindeki gökkuşağı alabalığı işletmelerinin kuruluş yeri, yllı, üretim durumu ve yerleşim merkezine uzaklığı

\begin{tabular}{lllll}
\hline İșletme no & Kuruluş yeri & Kuruluş yılı & Üretim durumu & Merkeze uzaklığı (Km) \\
\hline 1 & Ahlat & 1989 & Aktif & 63,3 \\
2 & Hizan & 2005 & Aktif & 46,0 \\
3 & Merkez & 2012 & Aktif & 10,1 \\
4 & Güroymak & 2004 & Aktif & 32,3 \\
5 & Adilcevaz & 1996 & Aktif & 98,1 \\
\hline
\end{tabular}

Yıldız ve Şener [6], Karadeniz Bölgesi'ndeki alabalık işletmelerinin \%96,1'inin herhangi bir yerleşim merkezine uzaklığının $20 \mathrm{~km}$ 'den az, \%33,9'unun ise $50 \mathrm{~km}$ 'den daha fazla mesafede olduğunu rapor etmişlerdir. Emre vd. [11], Akdeniz Bölgesi'ndeki alabalık işletmelerinin \%88'inin herhangi bir yerleşim birimine uzaklığının $20 \mathrm{~km}$ 'den daha az, \%2'sinin $51 \mathrm{~km}$ 'den fazla, \%10'unun ise 21-50 km arasında değişen bir mesafede olduğunu belirlemişlerdir. Rad ve Köksal [22]'a göre, Türkiye'deki alabalık işletmelerinin \%80'i en yakın yerleşim merkezine $20 \mathrm{~km}$ 'den daha az bir mesafede olup, \%20'si 20-50 km arasındadır. Doğan ve Yıldız [23], Marmara Bölgesi'ndeki alabalık işletmelerinin \%096,4'ünün en yakın yerleşim birimine uzaklığının $20 \mathrm{~km}$ 'den daha az, \%3,6'sının 20-50 km arasında değişen bir mesafede olduğu bildirmişlerdir. Bitlis'teki işletmelerin \%33,3'ünün merkeze uzaklığı 20 km'den az olup, \%66,7'si 32,3-98,1 km arasindadır.

\section{2. İşletmelerin arazi özellikleri}

Bitlis ilinde gökkuşağı alabalığ yamaçlarda ve \%40'1 ise açık arazide yetiştiricilik faaliyetlerini sürdürmektedir. Genellikle dik arazi yapısından dolayı tesis kurulumunda zorluklarla karşılaşıldığı işletme sahipleri tarafindan belirtilmiştir. İşletmelerin yer seçimi yaparken özellikle, kendi arazilerinden çıkan ya da yakın çevrelerinde bulunan su kaynaklarını tercih ettikleri belirlenmiştir. Aydın ve Sayılı [4]'ya göre, Samsun'daki karada alabalık üreten işletmelerin; \%20'si vadi arasında, \%40'1 dağ eteğinde ve \%40'1 ise açı arazide kurulmuşlardır. Kocaman vd. [24], Erzurum'da yaptıkları bir çalışmada; işletmelerin \%81'inin vadi arasında, $\% 14,2$ 'sinin dağ eteğinde ve \%4,8'inin ise açık arazide kurulduğunu tespit etmişlerdir. Adıgüzel ve Akay [25], Tokat'taki işletmelerin; \%47,37'sinin dağ eteğinde, \%31,58'inin açık arazide ve \%21,05'inin vadi arasında olduğunu bildirmişlerdir. Güneş ve Köprücü [26], Kahramanmaraş’taki işletmelerin $\% 50$ 'sinin vadi arasında, \%40'1nın dă eteğinde ve \%10'unun ise açık arazide kurulduğunu belirlemişlerdir. Karabulut ve Köprücü [27] Malatya'daki mevcut işletmelerin \%50'sinin vadi arasında, \%40'ının açık arazide ve \%10'unun ise dağ eteğinde kurulduğunu tespit etmişlerdir. İşletmelerin arazi durumları açısından kuruluş yerleri genellikle bölgenin coğrafik yapısı ve su kaynağına yakınlığıyla doğrudan ilişkilidir.

\section{3. Üretimde kullanılan su ve havuz özellikleri}

Bitlis ilindeki gökkuşağı alabalığı işletmelerinin \%80'inde kaynak suyu kullandığ1, \%20'sinin ise göl üzerinde üretim yaptığ 1 belirlenmiştir. Mevcut işletmelerin \%80'i beton havuzlarda, \%20'si ise ağ kafeslerde (Aygır Gölü'nde) üretim yapmaktadır. Beton havuzlarda balık yetiştiriciliği yapan tesislerin fiili üretim miktarları toplam üretimin \%94,3'ünü, ağ kafeslerde yapılan fiili üretim kapasitesi ise toplam üretimin \%5,7'sini oluşturmaktadır. Karadaki üretim toplam $6 \quad 019 \mathrm{~m}^{2}$ havuz alanında 
gerçekleştirilmektedir. Bu amaçla; yavru $\left(644 \mathrm{~m}^{2}\right)$, büyütme $\left(1500 \mathrm{~m}^{2}\right)$, anaç $\left(2364 \mathrm{~m}^{2}\right)$ ve pazarlama $\left(1511 \mathrm{~m}^{2}\right)$ havuzları kullanılmaktadır. Dikdörtgen, yamuk ve yuvarlak şekilli havuzlar mevcuttur. Karabulut ve Köprücü [27], Malatya'daki alabalık işletmelerin \%80'inin kaynak suyunu, \%20'sinin ise akarsuyu kullandıklarını tespit etmişlerdir. Gümüş ve Şahin [28]'e göre, Antalya'daki alabalık işletmelerinin \%91,4'ü kaynak suyu kullanmaktadır. İşletmelerin \%45,8'inde kullanılan suyun sıcaklığının $10^{\circ} \mathrm{C}$ 'nin altında olduğunu bildirmişlerdir. Bu durum alabalık üreten işletmelerin ağırlıklı bir şekilde kaynak suyu kullandıklarını göstermektedir.

\section{4. İşletmelerin yönetim yapısı ve sermaye kullanımı}

Bitlis ilinde gökkuşağı alabalığı üreten işletmelerin \%100'ünün şahıs işletmesi olduğu, şirket statüsünde veya ortaklı işletme şeklinde faaliyet gösteren işletme bulunmadığı tespit edilmiştir. İşletmelerin \%20'si üretimde öz sermaye kullanmakta, \%80'i ise öz sermayenin yanısıra teşviklerden de faydalanmaktadır. Karataş vd. [12]'ne göre Sivas'taki alabalık işletmelerinin; \%85,72'si şahıs, \%7,14'ü adi ortaklık ve $\% 7,14$ 'ü ise kamu kuruluşu şeklindedir. Yüksel [14]'e göre, Burdur'daki alabalık işletmelerinin yapısı; $\% 73,9$ gerçek kişi, \%21,5 şirket ve \%4,6 adi ortaklık şeklindedir. Gümüş vd. [16], Antalya' daki alabalık işletmelerinin yönetim yapısının; \%62,4 şahıs-aile, \%34,4 şirket-ortaklık ve \%3,2 kamu kuruluşu olduğunu belirlemişlerdir. Güneş ve Köprücü [26]'ye göre, Kahramanmaraş’taki alabalık işletmelerinin; \%60'1 şahıs-aile ve \%40'1 ise şirket-ortaklık şeklindedir. Karabulut ve Köprücü [27], Malatya'daki alabalık üreten işletmelerin şirket yapısının; \%50 şirket-ortaklık, \%40 şahıs-aile \%10 kooperatif olduğunu bildirmişlerdir. Bitlis’teki işletmelerin \%100'ünün şahıs işletmesi şeklinde olmasının en önemli nedeni; ekonomik sebeplerle tesislerin faaliyetlerine hep küçük kapasitelerde başlamaları ve üretimde sonuç aldıkça revize projelerle kapasite artırımına gitmeleridir. Henüz şirketleşecek düzeye gelemedikleri ve alt yapıyı sağlam temeller üzerine inşa edemedikleri için, ileriye atacakları adımlarda daha temkinli davrandıkları tespit edilmiştir.

\section{5. İşletme sahiplerinin yaş dağılımı, medeni durumu, eğitimi, sosyal güvencesi ve diğer mesleklerle olan ilişkisi}

Gökkuşağı alabalığı yetiştiriciliği yapan işletme sahiplerinin yaş dağılımı incelendiğinde; yaşları 44-52 arasında olanların oranı $\% 60,53-63$ arasında olanların ise $\% 40$ olduğu görülmüştür. Bu durum işletme sahiplerinin ağırlıklı olarak orta yaş grubunda olduğunu göstermektedir. İşletme sahiplerinin tamamı evli olup, \%40'1 ilkokul, \%20'si ortaokul ve \%40'1 ise lise mezunudur. Bunların \%80'i SGK' $11, \% 20$ 'si ise emeklidir. Bu kişilerin balık yetiştiriciliğinin yanısıra; \%40'1 balık avc1lığ 1 ve $\% 20$ 'si çiftçilik ve $\% 40$ 'ı ise muhtarlık işleriyle de uğraşmaktadır. Sadece balıkçılıkla uğraşanların işlerine daha iyi motive olduğu gözlemlenmiştir.

\section{6. Çalışan personelin sayısı, cinsiyeti ve eğitim durumu}

Bitlis ilindeki gökkuşağı alabalığı işletmelerinde çalışan toplam 20 personelden \%95 (19 kişi)'i erkek, $\% 5$ (1 kişi)'i ise bayandır. Bunların geneli aile fertlerinden oluşmaktadır. Aile fertleri dışında vasıflı ya da vasıfsız geçici işçiler, işlerin yoğun olduğu zamanlarda mevcut işçilere destek amaçlı çalıştırılmaktadır. Doğan ve Yıldız [23], Marmara Bölgesindeki alabalık işletmelerinin \%52,9'unda 13 personel, \%3,9'unda ise 21 veya daha fazla personel çalıştırıldığını bildirmişlerdir. Güneş ve Köprücü [26]'ye göre, Kahramanmaraş'taki alabalık işletmelerinin \%20'si 1-3 personel, \%50'si 4-9 personel ve $\% 30$ 'u ise 10 'dan fazla personel çalıştırmaktadır. Karabulut ve Köprücü [27], Malatya'daki alabalık üreten işletmelerde toplam 21 kişinin istihdam edildiğini; işletmelerin \%40'ında 1, \%30'unda 2 ve \%20'sinde ise 3 kişinin çalıştırıldığını tespit etmiş̧lerdir. Üstündağ vd. [29], Karadeniz Bölgesindeki işletmelerde 1-5 arasında değişen sayıda personel çalıştırıldığııı, sadece 1 personel çalıştıran işletmelerin oranının \%38,7 olduğunu belirtmişlerdir. Yapılan bu çalışmalar, mevcut işletmelerde kapasite arttıkça çalışan personel sayısının da arttığını göstermektedir. Bu işletmelerde çalışan personelin cinsiyet ve yaş dağılımına ait oranlar coğrafik bölgelere göre farkl1lık göstermektedir. Balık yetiştiriciliği kaba iş gücüne dayalı olduğundan, genellikle erkekler tarafindan tercih edilmektedir. $\mathrm{Bu}$ durum, mevcut işletmelerde çalışan kadın personel oranının düşük seviyede olmasını açıklamaktadır. 
Çalışan personelin eğitim seviyeleri incelendiğinde; \%70 (14 kişi)'nin ilköğretim, \%25 (5 kişi)'nin lise ve \%5 (1 kişi)'nin lisans mezunu olduğu görülmüştür. Gümüş vd. [16]'ne göre, Antalya'daki alabalık üreten işletmelerinde çalışan personelin; \%60,2'si işçi, \%32,9'u aile bireyi ve \%6,9'u ise su ürünleri mühendisidir. Doğan ve Yıldız [23], Marmara Bölgesindeki mevcut işletmelerde çalışan personelin; \%31,1'inin aile bireylerinden, \%33,8'inin vasıfsız işçilerden, \%25,6'sının eğitilmiş işçilerden, \%6,1'inin mühendislerden ve \%3,4'ünün teknikerlerden oluştuğunu bildirmişlerdir. Güneş ve Köprücü [26], Kahramanmaraş'taki alabalık işletmelerinde çalışan personelin en büyük kısmını işçilerin $(\% 76,40)$ oluşturduğunu, bunu sırasıyla aile bireyleri $(\% 18,86)$ ve su ürünleri mühendisleri $(\% 6,74)$ 'nin takip ettiğini belirlemişlerdir. Karabulut ve Köprücü [27], Malatya'daki alabalık üreten işletmelerde çalışan personelin \%14,28'inin mühendis, \%85,72'sinin ise vasıfsız işçilerden oluştuğunu, teknik eleman çalıştırılmadığını ve tüm personelin erkek olduğunu tespit etmişlerdir. Bitlis'teki alabalık işletmelerinde çalışan personelin niteliğine ait oranlar diğer araştırmacıların sonuçlarıyla benzerlik göstermektedir.

\subsection{Havuz ve kafeslerin bakımı ve dezenfeksiyonu, suyun analizi}

İşletmelerde beton havuzlar firça yardımı ile, kafes ağları ise güneşte kurutma, askıda çırpma ve basıççı suyla yıkama yöntemleri kullanılarak temizlenmekte, havuz tabanı ve duvarları sönmemiş kireç ile dezenfekte edilmektedir. Tesislerin \%20'si ayda bir, \%40'1 üç ayda bir ve \%40'1 ise altı ayda bir genel bakım ve temizlik işlerini yapmaktadır. İşletmelerin \%20'sinin su analizlerini İl Sağlı Müdürlügüne 6 ayda bir kez yaptırdığ $1, \% 80$ 'inin ise hiç yaptırmadığı tespit edilmiştir.

\section{8. İşletmelerdeki yavru balık üretimi}

Bitlis ilindeki gökkuşağı alabalığı işletmelerinin \%60’1 (3 işletme) ihtiyaç duydukları yıllık 6250000 adet yavru balığı kendi kuluçkahanelerinde üretirken, \%40’1 ise ihtiyaç duyduğu yıllık 130000 adet yavru balığı dışarıdan satın almaktadır (Tablo 2). Kendi yavru balığını üreten bu işletmeler bağımsız kuluçkahane binasına sahip olup, sadece bir kuluçkahanenin üst katı idari bina ve lokanta olarak kullanılmaktadır. İşletmelerde kuluçkahane binasında kullanılan suların giriş-çıkışları büyütme havuzlarından ayrı tutulmuş, böylece hastalık bulaşma riskinin en aza indirildiği görülmüsstür.

Tablo 2. Bitlis ilindeki gökkuşağı alabalığı işletmelerinin yavru balık üretim miktarları

\begin{tabular}{lll}
\hline İşletme no & Kendi üretimi (adet yavru balık/yıl) & Dışarıdan alım (adet yavru balık/yı) \\
1 & 5000000 & 0 \\
2 & 250000 & 0 \\
3 & - & 50000 \\
4 & 1000000 & 0 \\
5 & - & 80000 \\
\hline İl geneli & 6250000 & 130000 \\
\hline
\end{tabular}

Gümüş ve Şahin [28]'e göre, Antalya'daki alabalık işletmelerinin \%61,4'ü yumurta ve yavru balık ihtiyacının tamamını kendi üretimlerinden karşılarken, \%25'i üretim ile birlikte satın alma ve $\% 13,6$ 's ise sadece satın alma yoluna gitmektedir. Bu durum Bitlis'teki alabalık işletmeleriyle benzerlik göstermektedir.

\section{9. İşletmelerin üretim kapasitesi ve kapasite kullanımı}

Bitlis ilindeki gökkuşağı alabalığı üreten işletmelerin; yıllık proje kapasiteleri 25-100 ton, fiili kapasiteleri 9-100 ton ve kapasite kullanım oranları ise \%31,04-100 arasında değişmektedir. İl geneli toplam proje kapasitesinin 211 ton/yıl ve fiili kapasitenin 176 ton/yıl, ortalama kapasite kullanım oranının ise $\% 74,21 \pm 35,46(\mathrm{p}<0,05)$ olduğu belirlenmiştir (Tablo 3$)$. 
Tablo 3. Bitlis ilindeki gökkuşağı alabalığı işletmelerinin proje ve fiili kapasiteleri, kapasite kullanım oranları

\begin{tabular}{llll}
\hline İșletme no & Proje kapasitesi (ton/yil) & Fiili kapasite (ton/yıl) & Kapasite kullanım oranı (\%) \\
\hline 1 & 100 & 100 & 100 \\
2 & 29 & 29 & 100 \\
3 & 29 & 9 & 31,04 \\
4 & 28 & 28 & 100 \\
5 & 25 & 10 & 40,00 \\
\hline İl geneli & 211 & 176 & $74,21 \pm 35,46(p<0,05)$ \\
\hline
\end{tabular}

Güneş ve Köprücü [26], Kahramanmaraş’taki alabalık üreten işletmelerin kapasite kullanım oranlarını; küçük $(\% 69,98)$, orta $(\% 96,88)$ ve büyük $(\% 60)$ ölçekli işletmeler olarak bildirmişlerdir. Kahramanmaraş genelinde kapasite kullanım oranının \%73,98 olduğunu tespit etmişlerdir. Karabulut ve Köprücü [27]'ye göre, Malatya'daki alabalık üreten işletmelerin ortalama kapasite kullanım oranı $\% 40,6$ olup, bu oran küçük $(\% 59,85)$, orta $(\% 42,22)$ ve büyük $(\% 38,34)$ ölçekli işletmelerde istatistiksel olarak önemli $(\mathrm{p}<0,05)$ farklılıklar göstermektedir. Bitlis’teki alabalık işletmelerinin kapasite kullanım oranı (\%74,21), Kahramanmaraş’taki işletmelerle benzer olup, Malatya'dakilerden ise daha yüksektir. Bununla birlikte mevcut işletmelerin kapasitelerini tam anlamıla kullanamama sebepleri; kuluçkahane yönetimi hakkında yetersiz bilgiye sahip olmaları, dölleme ve yavru büyütme aşamasında kayıpların fazla olması, yeterli donanımlara sahip kalifiye elamanların bulunmaması, sermaye yetersizliği ve alt yapı sorunlarıdır.

\subsection{0. İşletmelerin taşınmaz varlıkları ve makine-ekipman durumu}

Bitlis ilindeki gökkuşağı alabalığı işletmelerinin hepsi idari bina, yem deposu, restorant ve balık satış yerlerine ve binek araçlara sahiptir. Tesislerin çevresindeki diğer alanlar da depolama amacıyla kullanılmaktadır. İşletmelerde kullanılan malzemeler; tesisin bulunduğu yerin özelliğine, alt yapısına ve üretimin kapasitesine bağlı olarak farklılıklar göstermektedir. Tesislerde soğuk hava deposu ve yem makinesi bulunmamaktadır. İhtiyaç halinde kullanılan soğutma dolaplarının yeterli olduğu belirtilmiştir. Ayrıca, 3 tesiste kuluçka dolabı, 4 tesiste boylama makinesi, 1 tesiste buz makinesi, 2 tesiste jeneratör ve multimetre, 1 tesiste ise kamyonet ve tekne mevcuttur.

\subsection{1. İşletmelerin bakım-onarım giderleri}

Bitlis ili genelinde, gökkuşağı alabalığ1 yetiştiriciliği yapan işletmelerin (yıllık toplam); "sabit harcamaları (Bina-havuz)" $25250 \mathrm{TL}$, "alet-makine bakım onarımı" $14000 \mathrm{TL}$, "arazi düzenleme giderleri" 15500 TL ve "su kullanım giderleri" 17000 TL'dir (Tablo 4). İşletmelerin giderleri arasında en büyük payı bina-havuz giderleri almaktadır. İşletmelerin giderleri; tesislerin büyüklüğüne, kullanılan yapı malzemesine, makine ve aletlere, yıllık üretim miktarına, personel sayısına, arazi yapısına, şehir ve girdi merkezlerine olan uzaklıklarına ve üretim periyodu içerisindeki balık ölümlerine bağlı olarak değişiklik göstermektedir.

Tablo 4. Bitlis ilindeki gökkuşağı alabalığ

\begin{tabular}{|c|c|c|c|c|c|}
\hline İşletme no & $\begin{array}{l}\text { Sabit harcamalar } \\
\text { (bina-havuz) }\end{array}$ & $\begin{array}{l}\text { Alet-makine } \\
\text { bakım ve onarımı }\end{array}$ & Arazi düzenleme & Su kullanımı & Toplam \\
\hline 1 & 10000 & 5500 & 9000 & 6000 & 30500 \\
\hline 2 & 5000 & 3000 & 5000 & 4500 & 17500 \\
\hline 3 & 2000 & 1000 & 500 & 1750 & 5250 \\
\hline 4 & 3000 & 2000 & 1000 & 1750 & 7750 \\
\hline 5 & 5250 & 2500 & - & 3000 & 10750 \\
\hline İl geneli & 25250 & 14000 & 15500 & 17000 & 71750 \\
\hline
\end{tabular}

\subsection{Yemin temini ve kullanımı}

Balıkların beslenmesinde genellikle peletlenmiş ekstrude yem kullanılmaktadır. Yemleme sıklığı; balığın verilen yemi almasına ve balıkların ortalama ağırlı̆̆ına göre değişkenlik göstermektedir. Yavru balıklar, yeme alıştırma döneminde günlük 6-7 kez, semirtme döneminde ortalama 3-4 kez, ortalama 
120 gr ağırlı̆ga ulaştıktan sonra ise günlük 1-2 kez yemlenmektedir. Yem ihtiyaçları ruhsatlı yem bayilerinden temin edilmektedir. İşletmelerin \%60'1 yem ödemelerini peşin olarak gerçekleştirirken \%40'1 vadeli ödeme yapmak durumunda olduklarını belirtmişlerdir.

\subsection{3. İşletmelerin ürünü pazarlama şekli}

Üretilen balıklar perakende veya toptan satış yöntemiyle pazarlanmaktadır. Bu işletmeler lokantaya sahip olduklarından, ürünlerini buralarda da tüketime sunmaktadırlar. Pazarlama şekilleri işletmelerin bulundukları yere göre farklılık göstermektedir. Örneğin; bir tesiste 150 gr'lık 2 adet balık porsiyon olarak tüketime sunulurken, diğer bir tesiste 300 gr olan 1 adet alabalık porsiyon olarak kullanılmaktadır. $\mathrm{Bu}$ gramajlarda pazarlanan alabalıkların pazar fiyatı ise lokantada uygulanan hizmet şekline ve pişirme yöntemlerine göre farkl1lık göstermektedir. Örneğin; bir işletmede kendin pişir kendin ye gibi imkânlar sunulurken, diğer bir tesiste farklı pişirme yöntemleri kullanarak tüketici kitlelerini belirlemektedirler. Bitlis ilinde balık işleme tesisi bulunmadığından, ürünün işlenerek pazarlanması söz konusu değildir. İşletmeler, ilin balık ihtiyacını ancak karşılayabildikleri için üretilen balıklar genelde iç piyasaya pazarlanmaktadır.

\subsection{Desteklemelerden yararlanma durumu}

Bitlis ilindeki gökkuşağ1 alabalığ işletmelerinin 2015-2018 yılları arasında aldıkları destek miktarları incelendiğinde (Tablo 5); desteklemelerden 2 işletmenin düzenli olarak, 2 işletmenin ise aralıklarla faydalandığı, 1 işletmenin ise bundan yararlanmadığı görülmektedir.

Tablo 5. Bitlis ilindeki gökkuşağı alabalığı işletmelerinin 2015-2018 yıllarında aldıkları destek miktarları (TL)

\begin{tabular}{llllll}
\hline İşletme no & $\mathbf{2 0 1 5}$ & $\mathbf{2 0 1 6}$ & $\mathbf{2 0 1 7}$ & $\mathbf{2 0 1 8}$ & Toplam \\
\hline 1 & 50648 & 20206 & 57750 & 0 & 128604 \\
2 & 18850 & 18849 & 21750 & 21750 & 81199 \\
3 & 6075 & 0 & 7010 & 7010 & 20095 \\
4 & 15718 & 17225 & 3136 & 19710 & 55789 \\
5 & 0 & 0 & 0 & 0 & 0 \\
\hline İl geneli & 91291 & 5628 & 89646 & 48470 & 285687 \\
\hline
\end{tabular}

\subsection{Bitlis’teki su kaynaklarının bazı fiziksel ve kimyasal özellikleri}

Bitlis ilindeki su kaynaklarının balık yetiştiriciliği potansiyelini belirlemek amacıyla; 3 adet göl, 23 adet yer altı suyu ve 11 adet dere ve çay olmak üzere toplam 37 su kaynağında çözünmüş oksijen, pH, nitrat, sıcaklık, bulanıklılık ve debi değerleri ölçülmüştür (Tablo 6-43).

Tablo 6. Tuğ Çayı analiz değerleri

\begin{tabular}{lllllll}
\hline Tuğ Çayı (Tatvan) & $\begin{array}{l}\text { Ilkbaha } \\
\text { r }\end{array}$ & Yaz & Sonbahar & Kiş & Ortalama \pm Ss & Önem derecesi \\
\hline Çözünmüş oksijen (mg/L) & 10,10 & 7,60 & 8,20 & 9,52 & $8,86 \pm 0,99$ & $\mathrm{p}<0,05$ \\
pH (ppm) & 6,55 & 5,98 & 7,26 & 7,81 & $6,90 \pm 0,69$ & $\mathrm{p}<0,05$ \\
Nitrat $(\mathrm{mg} / \mathrm{L})$ & 8,18 & 35,84 & 10,51 & 0,001 & $13,63 \pm 15,48$ & $\mathrm{p}<0,05$ \\
Sicaklık $\left({ }^{\circ} \mathrm{C}\right)$ & 12,60 & 13,75 & 9,22 & 6,11 & $10,42 \pm 2,99$ & $\mathrm{p}<0,05$ \\
Debi $(\mathrm{L} / \mathrm{sn})$ & 350 & 240 & 186 & 255 & $257,8 \pm 59,12$ & $\mathrm{p}<0,05$ \\
Bulanılık (JTU) & 17,00 & 8,60 & 11,80 & 10,20 & $11,90 \pm 3,15$ & $\mathrm{p}<0,05$ \\
\hline
\end{tabular}

Tablo 7. Harabeşehir Çayı analiz değerleri

\begin{tabular}{lllllll}
\hline $\begin{array}{l}\text { Harabeşehir Çayı } \\
(\text { Ahlat) }\end{array}$ & $\begin{array}{l}\text { Ilkbaha } \\
\mathbf{r}\end{array}$ & Yaz & Sonbahar & Kış & Ortalama \pm Ss & Önem derecesi \\
\hline Çözünmüş oksijen (mg/L) & 11,23 & 8,65 & 9,33 & 10,00 & $9,80 \pm 1,10$ & $\mathrm{p}<0,05$ \\
$\mathrm{pH}(\mathrm{ppm})$ & 6,63 & 5,99 & 7,04 & 6,87 & $6,63 \pm 0,46$ & $\mathrm{p}<0,05$ \\
Nitrat $(\mathrm{mg} / \mathrm{L})$ & 8,30 & 36,00 & 10,60 & 0,002 & $13,73 \pm 15,53$ & $\mathrm{p}<0,05$ \\
Sicaklık $\left({ }^{\circ} \mathrm{C}\right)$ & 10,33 & 19,22 & 11,50 & 9,05 & $12,53 \pm 4,57$ & $\mathrm{p}<0,05$ \\
Debi $(\mathrm{L} / \mathrm{sn})$ & 470 & 255 & 280 & 320 & $331,3 \pm 96,3$ & $\mathrm{p}<0,05$ \\
Bulanıklik (JTU) & 14,20 & 8,40 & 11,50 & 12,70 & $11,70 \pm 2,46$ & $\mathrm{p}<0,05$ \\
\hline
\end{tabular}


Tablo 8. Aygır Gölü analiz değerleri

\begin{tabular}{lllllll}
\hline Aygır Gölü (Adilcevaz) & İlkbaha & Yaz & Sonbahar & \multirow{2}{*}{ Kiş } & Ortalama \pm Ss & Önem derecesi \\
\hline Çözünmüş oksijen (mg/L) & 8,66 & 7,54 & 8,02 & 9,16 & $8,35 \pm 0,62$ & $\mathrm{p}<0,05$ \\
pH (ppm) & 7,90 & 7,22 & 7,02 & 7,44 & $7,40 \pm 0,33$ & $\mathrm{p}<0,05$ \\
Nitrat $(\mathrm{mg} / \mathrm{L})$ & 9,60 & 37,30 & 11,90 & 0,003 & $14,70 \pm 15,92$ & $\mathrm{p}<0,05$ \\
Sicaklık $\left({ }^{\circ} \mathrm{C}\right)$ & 11,20 & 22,95 & 14,09 & 9,39 & $14,41 \pm 5,21$ & $\mathrm{p}<0,05$ \\
Debi $(\mathrm{L} / \mathrm{sn})$ & - & - & - & - & - & - \\
Bulanıklik (JTU) & 3,10 & 1,20 & 2,40 & 1,60 & $2,08 \pm 0,73$ & $\mathrm{p}<0,05$ \\
\hline
\end{tabular}

Tablo 9. Ziyaret Menbası analiz değerleri

\begin{tabular}{lllllll}
\hline $\begin{array}{l}\text { Ziyaret Menbasi } \\
\text { (Güroymak) }\end{array}$ & Ilkbahar & Yaz & Sonbahar & Kış & Ortalama \pm Ss & $\begin{array}{l}\text { Önem } \\
\text { derecesi }\end{array}$ \\
\hline Çözünmüş oksijen (mg/L) & 7,86 & 6,51 & 7,97 & 7,90 & $7,56 \pm 0,61$ & $\mathrm{p}<0,05$ \\
pH (ppm) & 8,20 & 6,01 & 7,82 & 7,90 & $7,48 \pm 0,86$ & $\mathrm{p}<0,05$ \\
Nitrat $(\mathrm{mg} / \mathrm{L})$ & $<0,001$ & $<0,001$ & $<0,001$ & $<0,001$ & $0,00 \pm 0,00$ & - \\
Sicaklık ( $\left.{ }^{\circ} \mathrm{C}\right)$ & 12,28 & 13,76 & 10,32 & 8,60 & $11,24 \pm 1,95$ & $\mathrm{p}<0,05$ \\
Debi $(\mathrm{L} / \mathrm{sn})$ & 50,0 & 32,0 & 40,0 & 45,0 & $41,75 \pm 6,65$ & $\mathrm{p}<0,05$ \\
Bulaniklık (JTU) & 5,00 & 1,50 & 3,30 & 4,10 & $3,48 \pm 1,29$ & $\mathrm{p}<0,05$ \\
\hline
\end{tabular}

Tablo 10. Kümbet Suyu analiz değerleri

\begin{tabular}{lllllll}
\hline Kümbet Suyu (Güroymak) & İkbahar & Yaz & Sonbahar & Kış & Ortalama \pm Ss & $\begin{array}{l}\text { Önem } \\
\text { derecesi }\end{array}$ \\
\hline Çözünmüş oksijen (mg/L) & 6,75 & 5,54 & 6,90 & 6,98 & $6,54 \pm 0,59$ & $\mathrm{p}<0,05$ \\
pH (ppm) & 7,55 & 6,94 & 6,15 & 6,72 & $6,84 \pm 0,50$ & $\mathrm{p}<0,05$ \\
Nitrat (mg/L) & $<0,001$ & $<0,001$ & $<0,001$ & $<0,001$ & $0,00 \pm 0,00$ & - \\
Sicaklık ( $\left.{ }^{\circ} \mathrm{C}\right)$ & 10,26 & 10,74 & 9,95 & 10,04 & $10,25 \pm 0,31$ & $\mathrm{p}<0,05$ \\
Debi $(\mathrm{L} / \mathrm{sn})$ & 350 & 186 & 212 & 241 & $247,3 \pm 62,43$ & $\mathrm{p}<0,05$ \\
Bulanıklık (JTU) & 3,10 & 2,00 & 2,40 & 2,30 & $2,45 \pm 0,40$ & $\mathrm{p}<0,05$ \\
\hline
\end{tabular}

Tablo 11. Altınoluk Çayı analiz değerleri

\begin{tabular}{lllllll}
\hline Altınoluk Çayı (Hizan) & Ilkbahar & Yaz & Sonbahar & Kış & Ortalama \pm Ss & $\begin{array}{l}\text { Önem } \\
\text { derecesi }\end{array}$ \\
\hline Çözünmüş oksijen (mg/L) & 9,80 & 7,67 & 8,30 & 8,78 & $8,64 \pm 0,78$ & $\mathrm{p}<0,05$ \\
pH (ppm) & 7,30 & 7,75 & 7,82 & 7,11 & $7,50 \pm 0,30$ & $\mathrm{p}<0,05$ \\
Nitrat $(\mathrm{mg} / \mathrm{L})$ & 0,001 & $<0,001$ & $<0,001$ & 0,001 & $0,00 \pm 0,00$ & - \\
Sicaklık ( $\left.{ }^{\circ} \mathrm{C}\right)$ & 12,60 & 14,60 & 12,20 & 10,30 & $12,43 \pm 1,53$ & $\mathrm{p}<0,05$ \\
Debi (L/sn) & 350 & 200 & 250 & 300 & $275 \pm 55,90$ & $\mathrm{p}<0,05$ \\
Bulanıklık (JTU) & 1,00 & 0,20 & 0,80 & 0,60 & $0,65 \pm 0,30$ & $\mathrm{p}<0,05$ \\
\hline
\end{tabular}

Tablo 12. Mutki Deresi analiz değerleri

\begin{tabular}{lllllll}
\hline Mutki Deresi (Mutki) & İlkbahar & Yaz & Sonbahar & Kış & Ortalama \pm Ss & $\begin{array}{l}\text { Önem } \\
\text { derecesi }\end{array}$ \\
\hline Çözünmüş oksijen (mg/L) & 9,50 & 8,20 & 8,37 & 9,70 & $8,94 \pm 0,66$ & $\mathrm{p}<0,05$ \\
pH (ppm) & 7,35 & 7,98 & 7,22 & 6,96 & $7,38 \pm 0,38$ & $\mathrm{p}<0,05$ \\
Nitrat (mg/L) & 0,001 & 12,25 & 9,73 & 3,56 & $6,39 \pm 5,61$ & $\mathrm{p}<0,05$ \\
Sicaklik ( $\left.{ }^{\circ} \mathrm{C}\right)$ & 11,60 & 13,64 & 9,50 & 8,60 & $10,84 \pm 1,95$ & $\mathrm{p}<0,05$ \\
Debi (L/sn) & 280 & 150 & 180 & 260 & $217,5 \pm 54,03$ & $\mathrm{p}<0,05$ \\
Bulaniklık (JTU) & 14,30 & 9,50 & 11,40 & 13,80 & $12,25 \pm 1,93$ & $\mathrm{p}<0,05$ \\
\hline
\end{tabular}


Tablo 13. Yenibağ Deresi analiz değerleri

\begin{tabular}{lllllll}
\hline Yenibağ Deresi (Mutki) & İkbahar & Yaz & Sonbahar & Kış & Ortalama \pm Ss & $\begin{array}{l}\text { Önem } \\
\text { derecesi }\end{array}$ \\
\hline Çözünmüş oksijen (mg/L) & 8,80 & 6,40 & 7,50 & 7,39 & $7,52 \pm 0,85$ & $\mathrm{p}<0,05$ \\
pH (ppm) & 7,40 & 6,95 & 7,85 & 7,52 & $7,43 \pm 0,32$ & $\mathrm{p}<0,05$ \\
Nitrat $(\mathrm{mg} / \mathrm{L})$ & 0,001 & 12,31 & 9,82 & 3,67 & $6,45 \pm 5,63$ & $\mathrm{p}<0,05$ \\
Sicaklık $\left({ }^{\circ} \mathrm{C}\right)$ & 11,30 & 12,20 & 10,80 & 10,25 & $11,14 \pm 0,72$ & $\mathrm{p}<0,05$ \\
Debi $(\mathrm{L} / \mathrm{sn})$ & 100 & 45,0 & 60,0 & 75,0 & $70,0 \pm 20,31$ & $\mathrm{p}<0,05$ \\
Bulanıklık (JTU) & 6,60 & 4,30 & 5,50 & 5,70 & $5,53 \pm 0,82$ & $\mathrm{p}<0,05$ \\
\hline
\end{tabular}

Tablo 14. Bitlis Deresi analiz değerleri

\begin{tabular}{lllllll}
\hline Bitlis Deresi (Merkez) & İkbahar & Yaz & Sonbahar & Kiş & Ortalama \pm Ss & $\begin{array}{l}\text { Önem } \\
\text { derecesi }\end{array}$ \\
\hline Çözünmüş oksijen (mg/L) & 9,66 & 7,15 & 8,40 & 8,67 & $8,47 \pm 1,03$ & $\mathrm{p}<0,05$ \\
pH (ppm) & 7,22 & 8,30 & 7,56 & 7,82 & $7,73 \pm 0,46$ & $\mathrm{p}<0,05$ \\
Nitrat (mg/L) & 0,001 & 12,12 & 9,62 & 3,45 & $6,28 \pm 5,56$ & $\mathrm{p}<0,05$ \\
Sicaklık ( $\left.{ }^{\circ} \mathrm{C}\right)$ & 10,50 & 13,85 & 12,00 & 7,06 & $10,85 \pm 2,88$ & $\mathrm{p}<0,05$ \\
Debi (L/sn) & 530 & 250 & 360 & 450 & $397,5 \pm 120,4$ & $\mathrm{p}<0,05$ \\
Bulanıklik (JTU) & 16,70 & 10,10 & 11,40 & 12,80 & $12,75 \pm 2,86$ & $\mathrm{p}<0,05$ \\
\hline
\end{tabular}

Tablo 15. Duav Deresi analiz değerleri

\begin{tabular}{lllllll}
\hline Duav Deresi (Merkez) & Ilkbahar & Yaz & Sonbahar & Kış & Ortalama \pm Ss & $\begin{array}{l}\text { Önem } \\
\text { derecesi }\end{array}$ \\
\hline Çözünmüş oksijen (mg/L) & 8,25 & 7,60 & 7,82 & 8,10 & $7,94 \pm 0,25$ & $\mathrm{p}<0,05$ \\
pH (ppm) & 6,58 & 5,24 & 5,78 & 6,40 & $6,00 \pm 0,53$ & $\mathrm{p}<0,05$ \\
Nitrat $(\mathrm{mg} / \mathrm{L})$ & 0,001 & 12,40 & 9,91 & 3,76 & $6,52 \pm 5,66$ & $\mathrm{p}<0,05$ \\
Sicaklık ( $\left.{ }^{\circ} \mathrm{C}\right)$ & 12,50 & 14,60 & 10,50 & 8,63 & $11,56 \pm 2,23$ & $\mathrm{p}<0,05$ \\
Debi $(\mathrm{L} / \mathrm{sn})$ & 405 & 292 & 333 & 375 & $351,3 \pm 42,71$ & $\mathrm{p}<0,05$ \\
Bulanıklık (JTU) & 12,20 & 16,30 & 11,40 & 11,90 & $12,95 \pm 1,96$ & $\mathrm{p}<0,05$ \\
\hline
\end{tabular}

Tablo 16. Güroymak Şelalesi analiz değerleri

\begin{tabular}{lllllll}
\hline $\begin{array}{l}\text { Güroymak Şelalesi } \\
\text { (Güroymak) }\end{array}$ & İkbahar & Yaz & Sonbahar & Kış & Ortalama \pm Ss & $\begin{array}{l}\text { Önem } \\
\text { derecesi }\end{array}$ \\
\hline Çözünmüş oksijen (mg/L) & 11,12 & 10,30 & 10,80 & 11,50 & $10,93 \pm 0,44$ & $\mathrm{p}<0,05$ \\
pH (ppm) & 7,62 & 7,47 & 7,58 & 7,64 & $7,58 \pm 0,07$ & $\mathrm{p}>0,05$ \\
Nitrat $(\mathrm{mg} / \mathrm{L})$ & 4,24 & 7,52 & 4,11 & 8,89 & $6,19 \pm 2,39$ & $\mathrm{p}<0,05$ \\
Sicaklık $\left({ }^{\circ} \mathrm{C}\right)$ & 10,60 & 12,81 & 11,55 & 9,98 & $11,24 \pm 1,07$ & $\mathrm{p}<0,05$ \\
Debi $(\mathrm{L} / \mathrm{sn})$ & 300 & 260 & 270 & 280 & $277,5 \pm 14,79$ & $\mathrm{p}<0,05$ \\
Bulanıklık (JTU) & 1,20 & 0,60 & 0,80 & 0,90 & $0,88 \pm 0,22$ & $\mathrm{p}<0,05$ \\
\hline
\end{tabular}

Tablo 17. Aydınlar Suyu analiz değerleri

\begin{tabular}{lllllll}
\hline Aydınlar Suyu (Adilcevaz) & İlkbahar & Yaz & Sonbahar & Kış & Ortalama \pm Ss & $\begin{array}{l}\text { Önem } \\
\text { derecesi }\end{array}$ \\
\hline Çözünmüş oksijen (mg/L) & 7,60 & 6,80 & 7,55 & 7,48 & $7,36 \pm 0,33$ & $\mathrm{p}<0,05$ \\
pH (ppm) & 6,68 & 5,78 & 6,35 & 6,28 & $6,27 \pm 0,32$ & $\mathrm{p}<0,05$ \\
Nitrat $(\mathrm{mg} / \mathrm{L})$ & 0,001 & 5,42 & 0,001 & 10,41 & $3,96 \pm 5,00$ & $\mathrm{p}<0,05$ \\
Sicaklık $\left({ }^{\circ} \mathrm{C}\right)$ & 10,02 & 11,10 & 10,63 & 10,33 & $10,52 \pm 0,40$ & $\mathrm{p}<0,05$ \\
Debi $(\mathrm{L} / \mathrm{sn})$ & 161 & 118 & 146 & 137 & $140,5 \pm 15,57$ & $\mathrm{p}<0,05$ \\
Bulanıklık (JTU) & 2,60 & 1,80 & 1,90 & 1,50 & $1,95 \pm 0,40$ & $\mathrm{p}<0,05$ \\
\hline
\end{tabular}

Tablo 18. Aşağı Süphan Suyu analiz değerleri

\begin{tabular}{lllllll}
\hline $\begin{array}{l}\text { Aşă̆ı Süphan Suyu } \\
\text { (Adilcevaz) }\end{array}$ & İlkbahar & Yaz & Sonbahar & Kış & Ortalama \pm Ss & $\begin{array}{l}\text { Önem } \\
\text { derecesi }\end{array}$ \\
\hline Çözünmüş oksijen (mg/L) & 5,71 & 5,02 & 5,86 & 5,90 & $5,62 \pm 0,36$ & $\mathrm{p}<0,05$ \\
pH (ppm) & 7,60 & 7,95 & 7,80 & 7,45 & $7,70 \pm 0,19$ & $\mathrm{p}<0,05$ \\
Nitrat (mg/L) & 0,001 & 7,78 & 1,48 & 4,11 & $3,34 \pm 3,41$ & $\mathrm{p}<0,05$ \\
Sicaklık $\left({ }^{\circ} \mathrm{C}\right)$ & 9,76 & 10,90 & 10,54 & 9,93 & $10,28 \pm 0,46$ & $\mathrm{p}<0,05$ \\
Debi (L/sn) & 150 & 110 & 120 & 140 & $130 \pm 15,81$ & $\mathrm{p}<0,05$ \\
Bulanıklik (JTU) & 7,60 & 5,40 & 4,10 & 5,80 & $5,73 \pm 1,25$ & $\mathrm{p}<0,05$ \\
\hline
\end{tabular}


Tablo 19. Yolçatı Suyu analiz değerleri

\begin{tabular}{lllllll}
\hline Yolçatı Suyu (Adilcevaz) & İlkbahar & Yaz & Sonbahar & Kış & Ortalama \pm Ss & $\begin{array}{l}\text { Önem } \\
\text { derecesi }\end{array}$ \\
\hline Çözünmüş oksijen (mg/L) & 4,98 & 4,60 & 4,85 & 5,01 & $4,86 \pm 0,16$ & $\mathrm{p}<0,05$ \\
pH (ppm) & 7,80 & 7,95 & 7,80 & 8,20 & $7,94 \pm 0,16$ & $\mathrm{p}>0,05$ \\
Nitrat (mg/L) & 10,54 & 10,54 & 1,35 & $<0,001$ & $5,61 \pm 5,72$ & $\mathrm{p}<0,05$ \\
Sicaklık $\left({ }^{\circ} \mathrm{C}\right)$ & 10,16 & 10,97 & 10,54 & 9,96 & $10,41 \pm 0,39$ & $\mathrm{p}<0,05$ \\
Debi $(\mathrm{L} / \mathrm{sn})$ & 130 & 80,0 & 85,0 & 110 & $101,3 \pm 20,12$ & $\mathrm{p}<0,05$ \\
Bulanıklik (JTU) & 6,50 & 4,80 & 5,70 & 6,00 & $5,75 \pm 0,62$ & $\mathrm{p}<0,05$ \\
\hline
\end{tabular}

Tablo 20. Çanakyayla Suyu analiz değerleri

\begin{tabular}{lllllll}
\hline $\begin{array}{l}\text { Çanakyayla Suyu } \\
\text { (Adilcevaz) }\end{array}$ & Ilkbahar & Yaz & Sonbahar & Kiş & Ortalama \pm Ss & $\begin{array}{l}\text { Önem } \\
\text { Derecesi }\end{array}$ \\
\hline Çözünmüş oksijen (mg/L) & 5,36 & 5,05 & 5,18 & 5,28 & $5,22 \pm 0,12$ & $\mathrm{p}<0,05$ \\
pH (ppm) & 6,69 & 7,06 & 7,53 & 7,84 & $7,28 \pm 0,44$ & $\mathrm{p}<0,05$ \\
Nitrat (mg/L) & 0,001 & 3,58 & 0,001 & 13,96 & $4,39 \pm 6,60$ & $\mathrm{p}<0,05$ \\
Sicaklık ( $\left.{ }^{\circ} \mathrm{C}\right)$ & 10,21 & 10,94 & 9,24 & 9,15 & $9,89 \pm 0,74$ & $\mathrm{p}<0,05$ \\
Debi (L/sn) & 140 & 90,0 & 110 & 130 & $117,5 \pm 19,20$ & $\mathrm{p}<0,05$ \\
Bulaniklik (JTU) & 3,30 & 1,50 & 2,70 & 2,60 & $2,53 \pm 0,65$ & $\mathrm{p}<0,05$ \\
\hline
\end{tabular}

Tablo 21. Harmantepe Suyu analiz değerleri

\begin{tabular}{lllllll}
\hline $\begin{array}{l}\text { Harmantepe Suyu } \\
\text { (Adilcevaz) }\end{array}$ & İkbahar & Yaz & Sonbahar & Kış & Ortalama \pm Ss & $\begin{array}{l}\text { Önem } \\
\text { derecesi }\end{array}$ \\
\hline Çözünmüş Oksijen (mg/L) & 5,10 & 4,39 & 4,86 & 4,90 & $4,81 \pm 0,26$ & $\mathrm{p}<0,05$ \\
pH (ppm) & 6,66 & 7,25 & 7,36 & 6,95 & $7,06 \pm 0,27$ & $\mathrm{p}<0,05$ \\
Nitrat $(\mathrm{mg} / \mathrm{L})$ & 0,001 & 8,97 & 0,001 & 17,77 & $6,69 \pm 8,51$ & $\mathrm{p}<0,05$ \\
Sicaklık ( $\left.{ }^{\circ} \mathrm{C}\right)$ & 11,60 & 12,30 & 11,28 & 10,94 & $11,53 \pm 0,50$ & $\mathrm{p}<0,05$ \\
Debi $(\mathrm{L} / \mathrm{sn})$ & 200 & 145 & 130 & 180 & $163,8 \pm 27,70$ & $\mathrm{p}<0,05$ \\
Bulanıklık (JTU) & 4,90 & 2,20 & 3,70 & 3,50 & $3,58 \pm 0,96$ & $\mathrm{p}<0,05$ \\
\hline
\end{tabular}

Tablo 22. Kınalıkoç Suyu analiz değerleri

\begin{tabular}{lllllll}
\hline Kınalıkoç Suyu (Ahlat) & Ilkbahar & Yaz & Sonbahar & Kış & Ortalama \pm Ss & $\begin{array}{l}\text { Önem } \\
\text { derecesi }\end{array}$ \\
\hline Çözünmüş oksijen (mg/L) & 5,50 & 5,21 & 5,66 & 5,32 & $5,42 \pm 0,17$ & $\mathrm{p}<0,05$ \\
pH (ppm) & 6,55 & 7,30 & 7,51 & 7,44 & $7,20 \pm 0,38$ & $\mathrm{p}<0,05$ \\
Nitrat $(\mathrm{mg} / \mathrm{L})$ & 0,001 & 8,7 & 0,001 & 10,80 & $4,88 \pm 5,69$ & $\mathrm{p}<0,05$ \\
Sicaklık $\left({ }^{\circ} \mathrm{C}\right)$ & 10,60 & 11,78 & 11,17 & 10,13 & $10,92 \pm 0,62$ & $\mathrm{p}<0,05$ \\
Debi $(\mathrm{L} / \mathrm{sn})$ & 260 & 150 & 130 & 215 & $188,8 \pm 51,77$ & $\mathrm{p}<0,05$ \\
Bulanıklık (JTU) & 3,20 & 1,60 & 2,40 & 2,60 & $2,45 \pm 0,57$ & $\mathrm{p}<0,05$ \\
\hline
\end{tabular}

Tablo 23. Ovakışla Suyu analiz değerleri

\begin{tabular}{lllllll}
\hline Ovakışla Suyu (Ahlat) & İkbahar & Yaz & Sonbahar & Kış & Ortalama \pm Ss & $\begin{array}{l}\text { Önem } \\
\text { derecesi }\end{array}$ \\
\hline Çözünmüş oksijen (mg/L) & 6,80 & 6,47 & 6,75 & 6,70 & $6,68 \pm 0,13$ & $\mathrm{p}>0,05$ \\
pH (ppm) & 7,65 & 7,42 & 7,88 & 7,59 & $7,64 \pm 0,17$ & $\mathrm{p}<0,05$ \\
Nitrat $(\mathrm{mg} / \mathrm{L})$ & 0,001 & 0,001 & 0,001 & 9,89 & $2,47 \pm 4,95$ & $\mathrm{p}<0,05$ \\
Sicaklık $\left({ }^{\circ} \mathrm{C}\right)$ & 10,27 & 10,97 & 10,61 & 9,43 & $10,32 \pm 0,57$ & $\mathrm{p}<0,05$ \\
Debi $(\mathrm{L} / \mathrm{sn})$ & 385 & 190 & 250 & 310 & $283,8 \pm 72,23$ & $\mathrm{p}<0,05$ \\
Bulanıklık (JTU) & 2,00 & 0,40 & 1,60 & 1,30 & $1,33 \pm 0,59$ & $\mathrm{p}<0,05$ \\
\hline
\end{tabular}

Tablo 24. Saka Suyu analiz değerleri

\begin{tabular}{lllllll}
\hline Saka Suyu (Ahlat) & Ilkbahar & Yaz & Sonbahar & Kış & Ortalama \pm Ss & $\begin{array}{l}\text { Önem } \\
\text { derecesi }\end{array}$ \\
\hline Çözünmüş oksijen (mg/L) & 4,94 & 4,45 & 4,86 & 4,90 & $4,79 \pm 0,20$ & $\mathrm{p}<0,05$ \\
pH (ppm) & 6,52 & 5,94 & 7,62 & 7,88 & $6,99 \pm 0,79$ & $\mathrm{p}<0,05$ \\
Nitrat (mg/L) & 0,001 & 7,13 & 7,39 & 1,35 & $3,97 \pm 3,84$ & $\mathrm{p}<0,05$ \\
Sicaklık ( $\left.{ }^{\circ} \mathrm{C}\right)$ & 11,17 & 12,06 & 11,02 & 10,63 & $11,22 \pm 0,52$ & $\mathrm{p}<0,05$ \\
Debi (L/sn) & 65,00 & 25,00 & 40,00 & 55,00 & $46,25 \pm 15,26$ & $\mathrm{p}<0,05$ \\
Bulanıklık (JTU) & 14,80 & 11,20 & 13,80 & 13,50 & $13,25 \pm 1,32$ & $\mathrm{p}<0,05$ \\
\hline
\end{tabular}


Tablo 25. Taşharman Suyu analiz değerleri

\begin{tabular}{|c|c|c|c|c|c|c|}
\hline Taşharman Suyu (Ahlat) & İlkbahar & Yaz & Sonbahar & Kış & Ortalama \pm Ss & $\begin{array}{l}\text { Önem } \\
\text { derecesi }\end{array}$ \\
\hline Çözünmüş oksijen (mg/L) & 5,83 & 5,29 & 5,74 & 5,90 & $5,69 \pm 0,24$ & $\mathrm{p}<0,05$ \\
\hline $\mathrm{pH}(\mathrm{ppm})$ & 7,25 & 7,56 & 7,51 & 7,21 & $7,38 \pm 0,15$ & $\mathrm{p}>0,05$ \\
\hline Nitrat (mg/L) & 0,43 & 0,001 & 3,06 & 2,40 & $1,47 \pm 1,49$ & $\mathrm{p}<0,05$ \\
\hline Sicaklik $\left({ }^{\circ} \mathrm{C}\right)$ & 10,41 & 12,36 & 10,28 & 9,65 & $10,68 \pm 1,01$ & $\mathrm{p}<0,05$ \\
\hline Debi (L/sn) & 90,00 & 80,00 & 82,00 & 90,00 & $85,50 \pm 4,56$ & $\mathrm{p}<0,05$ \\
\hline Bulanıklık (JTU) & 11,30 & 8,70 & 10,05 & 10,36 & $10,10 \pm 0,93$ & $\mathrm{p}<0,05$ \\
\hline \multicolumn{7}{|c|}{ Tablo 26. Yumurtatepe Suyu analiz değerleri } \\
\hline $\begin{array}{l}\text { Yumurtatepe Suyu } \\
\text { (Tatvan) }\end{array}$ & İlkbahar & $\mathbf{Y a z}$ & Sonbahar & Kiş & Ortalama \pm Ss & $\begin{array}{l}\text { Önem } \\
\text { derecesi }\end{array}$ \\
\hline Çözünmüş oksijen (mg/L) & 7,50 & 6,84 & 7,25 & 7,33 & $7,23 \pm 0,24$ & $\mathrm{p}<0,05$ \\
\hline $\mathrm{pH}(\mathrm{ppm})$ & 6,06 & 7,41 & 6,58 & 7,24 & $6,82 \pm 0,54$ & $\mathrm{p}<0,05$ \\
\hline Nitrat (mg/L) & 0,001 & 0,001 & 4,11 & 0,001 & $1,03 \pm 2,06$ & $\mathrm{p}<0,05$ \\
\hline Sicaklik $\left({ }^{\circ} \mathrm{C}\right)$ & 10,80 & 12,22 & 10,54 & 9,85 & $10,85 \pm 0,86$ & $\mathrm{p}<0,05$ \\
\hline Debi (L/sn) & 32,00 & 20,00 & 23,00 & 26,00 & $25,25 \pm 4,44$ & $\mathrm{p}<0,05$ \\
\hline Bulanıklık (JTU) & 8,70 & 6,70 & 7,70 & 7,30 & $7,60 \pm 0,73$ & $\mathrm{p}<0,05$ \\
\hline
\end{tabular}

Tablo 27. Çekmece Suyu analiz değerleri

\begin{tabular}{lllllll}
\hline Çekmece Suyu (Tatvan) & İlkbahar & Yaz & Sonbahar & Kış & Ortalama \pm Ss & $\begin{array}{l}\text { Önem } \\
\text { Derecesi }\end{array}$ \\
\hline Çözünmüş oksijen (mg/L) & 5,50 & 4,82 & 4,95 & 5,13 & $5,10 \pm 0,26$ & $\mathrm{p}<0,05$ \\
pH (ppm) & 6,77 & 6,38 & 6,45 & 6,91 & $6,63 \pm 0,22$ & $\mathrm{p}<0,05$ \\
Nitrat $(\mathrm{mg} / \mathrm{L})$ & 0,001 & 2,92 & 0,001 & 21,97 & $6,22 \pm 10,59$ & $\mathrm{p}<0,05$ \\
Sicaklık ( $\left.{ }^{\circ} \mathrm{C}\right)$ & 12,34 & 13,86 & 11,17 & 10,97 & $12,09 \pm 1,15$ & $\mathrm{p}<0,05$ \\
Debi $(\mathrm{L} / \mathrm{sn})$ & 25,00 & 15,00 & 18,00 & 20,00 & $19,50 \pm 3,64$ & $\mathrm{p}<0,05$ \\
Bulanıklık (JTU) & 3,90 & 2,10 & 2,60 & 3,20 & $2,95 \pm 0,67$ & $\mathrm{p}<0,05$ \\
\hline
\end{tabular}

Tablo 28. Kuruyaka Suyu analiz değerleri

\begin{tabular}{lllllll}
\hline Kuruyaka Suyu (Tatvan) & İlkbahar & Yaz & Sonbahar & Kış & Ortalama \pm Ss & $\begin{array}{l}\text { Önem } \\
\text { derecesi }\end{array}$ \\
\hline Çözünmüş oksijen (mg/L) & 6,48 & 5,26 & 6,17 & 6,33 & $6,06 \pm 0,48$ & $\mathrm{p}<0,05$ \\
pH (ppm) & 6,77 & 7,49 & 6,85 & 7,47 & $7,15 \pm 0,34$ & $\mathrm{p}<0,05$ \\
Nitrat (mg/L) & 0,001 & 4,89 & 0,001 & 0,70 & $1,40 \pm 2,35$ & $\mathrm{p}<0,05$ \\
Sicaklık ( $\left.{ }^{\circ} \mathrm{C}\right)$ & 10,28 & 11,68 & 10,01 & 9,91 & $10,47 \pm 0,71$ & $\mathrm{p}<0,05$ \\
Debi (L/sn) & 35,00 & 24,00 & 19,00 & 25,00 & $25,75 \pm 5,80$ & $\mathrm{p}<0,05$ \\
Bulanılık (JTU) & 7,30 & 5,80 & 8,49 & 7,07 & $7,17 \pm 0,96$ & $\mathrm{p}<0,05$ \\
\hline
\end{tabular}

Tablo 29. Göllü Suyu analiz değerleri

\begin{tabular}{lllllll}
\hline Göllü Suyu (Tatvan) & İlkbahar & Yaz & Sonbahar & Kış & Ortalama \pm Ss & $\begin{array}{l}\text { Önem } \\
\text { derecesi }\end{array}$ \\
\hline Çözünmüş oksijen (mg/L) & 5,10 & 4,60 & 4,80 & 5,08 & $4,90 \pm 0,24$ & $\mathrm{p}<0,05$ \\
pH (ppm) & 6,87 & 7,25 & 7,12 & 6,90 & $7,04 \pm 0,18$ & $\mathrm{p}<0,05$ \\
Nitrat (mg/L) & 0,001 & 12,12 & 8,31 & 14,35 & $8,70 \pm 6,31$ & $\mathrm{p}<0,05$ \\
Sicaklık ( $\left.{ }^{\circ} \mathrm{C}\right)$ & 10,60 & 11,72 & 9,91 & 9,63 & $10,47 \pm 0,93$ & $\mathrm{p}<0,05$ \\
Debi (L/sn) & 55,00 & 45,00 & 45,00 & 50,00 & $48,75 \pm 4,79$ & $\mathrm{p}<0,05$ \\
Bulanılik (JTU) & 5,20 & 3,80 & 4,10 & 4,80 & $4,48 \pm 0,64$ & $\mathrm{p}<0,05$ \\
\hline
\end{tabular}

Tablo 30. Gölbaşı Suyu analiz değerleri

\begin{tabular}{lllllll}
\hline Gölbaşı Suyu (Güroymak) & İkbahar & Yaz & Sonbahar & Kış & Ortalama \pm Ss & $\begin{array}{l}\text { Önem } \\
\text { derecesi }\end{array}$ \\
\hline Çözünmüş oksijen (mg/L) & 9,24 & 8,65 & 8,86 & 9,12 & $8,97 \pm 0,23$ & $\mathrm{p}<0,05$ \\
pH (ppm) & 6,80 & 7,24 & 7,26 & 7,11 & $7,10 \pm 0,18$ & $\mathrm{p}<0,05$ \\
Nitrat (mg/L) & 0,001 & 11,99 & 0,001 & 0,001 & $3,00 \pm 6,00$ & $\mathrm{p}<0,05$ \\
Sicaklık ( $\left.{ }^{\circ} \mathrm{C}\right)$ & 9,50 & 10,20 & 9,22 & 9,13 & $9,51 \pm 0,42$ & $\mathrm{p}<0,05$ \\
Debi $(\mathrm{L} / \mathrm{sn})$ & 165 & 138 & 130 & 145 & $144,5 \pm 12,97$ & $\mathrm{p}<0,05$ \\
Bulanıklı (JTU) & 2,10 & 1,30 & 1,50 & 1,80 & $1,68 \pm 0,30$ & $\mathrm{p}<0,05$ \\
\hline
\end{tabular}


Tablo 31. Güzelli Suyu analiz değerleri

\begin{tabular}{|c|c|c|c|c|c|c|}
\hline Güzelli Suyu (Güroymak) & İlkbahar & $\mathbf{Y a z}$ & Sonbahar & Kış & Ortalama \pm Ss & $\begin{array}{l}\text { Önem } \\
\text { derecesi }\end{array}$ \\
\hline Çözünmüş oksijen (mg/L) & 8,40 & 8,02 & 8,30 & 8,50 & $8,31 \pm 0,18$ & $\mathrm{p}<0,05$ \\
\hline $\mathrm{pH}(\mathrm{ppm})$ & 7,41 & 7,56 & 7,50 & 7,81 & $7,57 \pm 0,15$ & $\mathrm{p}<0,05$ \\
\hline Nitrat (mg/L) & 0,001 & 7,65 & 0,001 & 4,76 & $3,10 \pm 3,77$ & $\mathrm{p}<0,05$ \\
\hline Sicaklık $\left({ }^{\circ} \mathrm{C}\right)$ & 9,60 & 10,07 & 9,46 & 9,10 & $9,56 \pm 0,35$ & $\mathrm{p}<0,05$ \\
\hline Debi (L/sn) & 105 & 81,00 & 79,00 & 84,00 & $87,25 \pm 10,40$ & $\mathrm{p}<0,05$ \\
\hline Bulanıklık (JTU) & 1,80 & 0,70 & 1,20 & 1,50 & $1,30 \pm 0,41$ & $\mathrm{p}<0,05$ \\
\hline \multicolumn{7}{|c|}{ Tablo 32. Değirmenköy Suyu analiz değerleri } \\
\hline $\begin{array}{l}\text { Değirmenköy Suyu } \\
\text { (Güroymak) }\end{array}$ & İlkbahar & $\mathbf{Y a z}$ & Sonbahar & Kış & Ortalama \pm Ss & $\begin{array}{l}\text { Önem } \\
\text { derecesi }\end{array}$ \\
\hline Çözünmüş oksijen (mg/L) & 7,93 & 7,26 & 7,55 & 7,68 & $7,61 \pm 0,24$ & $\mathrm{p}<0,05$ \\
\hline $\mathrm{pH}(\mathrm{ppm})$ & 7,30 & 7,74 & 7,56 & 7,48 & $7,52 \pm 0,16$ & $\mathrm{p}<0,05$ \\
\hline Nitrat (mg/L) & 0,001 & 9,23 & 0,001 & 13,96 & $5,80 \pm 6,97$ & $\mathrm{p}<0,05$ \\
\hline Sicaklık $\left({ }^{\circ} \mathrm{C}\right)$ & 11,36 & 13,25 & 10,78 & 10,35 & $11,44 \pm 1,11$ & $\mathrm{p}<0,05$ \\
\hline Debi (L/sn) & 125 & 111 & 104 & 106 & $111,5 \pm 8,20$ & $\mathrm{p}<0,05$ \\
\hline Bulanıklık (JTU) & 10,02 & 5,70 & 6,20 & 6,10 & $7,01 \pm 1,75$ & $\mathrm{p}<0,05$ \\
\hline
\end{tabular}

Tablo 33. Üzümveren Suyu analiz değerleri

\begin{tabular}{lllllll}
\hline $\begin{array}{l}\text { Üzümveren Suyu } \\
\text { (Güroymak) }\end{array}$ & Ilkbahar & Yaz & Sonbahar & Kış & Ortalama \pm Ss & $\begin{array}{l}\text { Önem } \\
\text { derecesi }\end{array}$ \\
\hline Çözünmüş oksijen (mg/L) & 7,39 & 7,25 & 7,46 & 7,45 & $7,39 \pm 0,08$ & $\mathrm{p}>0,05$ \\
pH (ppm) & 6,15 & 7,04 & 6,17 & 6,21 & $6,39 \pm 0,38$ & $\mathrm{p}<0,05$ \\
Nitrat $(\mathrm{mg} / \mathrm{L})$ & 0,001 & 3,97 & 0,001 & 0,001 & $0,99 \pm 1,99$ & $\mathrm{p}<0,05$ \\
Sicaklık ( $\left.{ }^{\circ} \mathrm{C}\right)$ & 10,60 & 10,82 & 9,63 & 9,57 & $10,16 \pm 0,56$ & $\mathrm{p}<0,05$ \\
Debi $(\mathrm{L} / \mathrm{sn})$ & 41,00 & 35,00 & 30,00 & 36,00 & $35,50 \pm 3,91$ & $\mathrm{p}<0,05$ \\
Bulaniklık (JTU) & 3,30 & 1,80 & 2,60 & 2,10 & $2,45 \pm 0,57$ & $\mathrm{p}<0,05$ \\
\hline
\end{tabular}

Tablo 34. Altınkalbur Suyu analiz değerleri

\begin{tabular}{lllllll}
\hline Altınkalbur Suyu (Merkez) & İlkbahar & Yaz & Sonbahar & Kış & Ortalama \pm Ss & $\begin{array}{l}\text { Önem } \\
\text { derecesi }\end{array}$ \\
\hline Çözünmüş oksijen (mg/L) & 7,15 & 6,39 & 6,95 & 6,48 & $6,74 \pm 0,32$ & $\mathrm{p}<0,05$ \\
pH (ppm) & 7,46 & 7,12 & 7,26 & 7,32 & $7,29 \pm 0,12$ & $\mathrm{p}>0,05$ \\
Nitrat $(\mathrm{mg} / \mathrm{L})$ & $<0,001$ & $<0,001$ & $<0,001$ & 0,001 & $0,00 \pm 0,00$ & - \\
Sicaklık $\left({ }^{\circ} \mathrm{C}\right)$ & 10,18 & 10,78 & 10,03 & 9,73 & $10,18 \pm 0,38$ & $\mathrm{p}<0,05$ \\
Debi $(\mathrm{L} / \mathrm{sn})$ & 17,00 & 9,00 & 10,00 & 10,00 & $11,50 \pm 3,20$ & $\mathrm{p}<0,05$ \\
Bulanıklik (JTU) & 1,30 & 0,40 & 0,60 & 0,50 & $0,70 \pm 0,35$ & $\mathrm{p}<0,05$ \\
\hline
\end{tabular}

Tablo 35. İçmeli Suyu analiz değerleri

\begin{tabular}{lllllll}
\hline İçmeli Suyu (Merkez) & Ilkbahar & Yaz & Sonbahar & Kış & Ortalama \pm Ss & $\begin{array}{l}\text { Önem } \\
\text { derecesi }\end{array}$ \\
\hline Çözünmüş̧ oksijen (mg/L) & 8,89 & 8,15 & 8,23 & 8,41 & $8,42 \pm 0,29$ & $\mathrm{p}<0,05$ \\
pH (ppm) & 7,59 & 7,51 & 7,94 & 7,66 & $7,68 \pm 0,16$ & $\mathrm{p}<0,05$ \\
Nitrat (mg/L) & 0,001 & 7,76 & 0,001 & 4,87 & $3,16 \pm 3,83$ & $\mathrm{p}<0,05$ \\
Sicaklık ( $\left.{ }^{\circ} \mathrm{C}\right)$ & 10,63 & 11,23 & 10,16 & 9,89 & $10,48 \pm 0,51$ & $\mathrm{p}<0,05$ \\
Debi (L/sn) & 293 & 226 & 210 & 250 & $244,8 \pm 31,28$ & $\mathrm{p}<0,05$ \\
Bulanıklık (JTU) & 8,10 & 3,50 & 3,60 & 4,10 & $4,83 \pm 1,90$ & $\mathrm{p}<0,05$ \\
\hline
\end{tabular}

Tablo 36. Yumurtatepe Suyu analiz değerleri

\begin{tabular}{lllllll}
\hline $\begin{array}{l}\text { Yumurtatepe Suyu } \\
\text { (Merkez) }\end{array}$ & Ilkbahar & Yaz & Sonbahar & Kiş & Ortalama \pm Ss & $\begin{array}{l}\text { Önem } \\
\text { derecesi }\end{array}$ \\
\hline Çözünmüş oksijen (mg/L) & 9,10 & 8,67 & 8,23 & 9,25 & $8,81 \pm 0,40$ & $\mathrm{p}<0,05$ \\
pH (ppm) & 6,81 & 7,23 & 7,15 & 7,02 & $7,05 \pm 0,16$ & $\mathrm{p}<0,05$ \\
Nitrat (mg/L) & $<0,001$ & $<0,001$ & $<0,001$ & 0,001 & $0,00 \pm 0,00$ & - \\
Sicaklık ( $\left.{ }^{\circ} \mathrm{C}\right)$ & 11,63 & 12,14 & 11,57 & 10,70 & $11,51 \pm 0,52$ & $\mathrm{p}<0,05$ \\
Debi $(\mathrm{L} / \mathrm{sn})$ & 11,00 & 4,00 & 5,00 & 7,00 & $6,75 \pm 2,68$ & $\mathrm{p}<0,05$ \\
Bulanıklik (JTU) & 0,80 & 0,40 & 0,40 & 0,60 & $0,55 \pm 0,17$ & $\mathrm{p}<0,05$ \\
\hline
\end{tabular}


Tablo 37. Sapur Çayı analiz değerleri

\begin{tabular}{lllllll}
\hline Sapur Çayı (Tatvan) & Ilkbahar & Yaz & Sonbahar & Kış & Ortalama \pm Ss & $\begin{array}{l}\text { Önem } \\
\text { derecesi }\end{array}$ \\
\hline Çözünmüş oksijen (mg/L) & 9,63 & 8,74 & 9,12 & 9,52 & $9,25 \pm 0,35$ & $\mathrm{p}<0,05$ \\
pH (ppm) & 6,53 & 6,88 & 7,26 & 7,14 & $6,95 \pm 0,28$ & $\mathrm{p}<0,05$ \\
Nitrat (mg/L) & $<0,001$ & $<0,001$ & $<0,001$ & 0,001 & $0,00 \pm 0,00$ & - \\
Sicaklık ( $\left.{ }^{\circ} \mathrm{C}\right)$ & 9,95 & 10,76 & 9,22 & 8,14 & $9,52 \pm 0,96$ & $\mathrm{p}<0,05$ \\
Debi (L/sn) & 319 & 277 & 249 & 258 & $275,8 \pm 26,94$ & $\mathrm{p}<0,05$ \\
Bulanıklik (JTU) & 10,03 & 5,89 & 6,61 & 6,23 & $7,19 \pm 1,66$ & $\mathrm{p}<0,05$ \\
\hline
\end{tabular}

Tablo 38. Adabağ Suyu analiz değerleri

\begin{tabular}{lllllll}
\hline Adabă̆ Suyu (Tatvan) & İkbahar & Yaz & Sonbahar & Kış & Ortalama \pm Ss & $\begin{array}{l}\text { Önem } \\
\text { derecesi }\end{array}$ \\
\hline Çözünmüş oksijen (mg/L) & 5,55 & 5,21 & 5,34 & 6,07 & $5,54 \pm 0,33$ & $\mathrm{p}<0,05$ \\
pH (ppm) & 7,02 & 6,98 & 7,13 & 7,46 & $7,15 \pm 0,19$ & $\mathrm{p}<0,05$ \\
Nitrat $(\mathrm{mg} / \mathrm{L})$ & $<0,001$ & $<0,001$ & $<0,001$ & 0,001 & $0,00 \pm 0,00$ & - \\
Sicaklık $\left({ }^{\circ} \mathrm{C}\right)$ & 11,63 & 12,85 & 10,87 & 10,66 & $11,50 \pm 0,86$ & $\mathrm{p}<0,05$ \\
Debi $(\mathrm{L} / \mathrm{sn})$ & 24,00 & 20,00 & 20,00 & 22,00 & $21,50 \pm 1,66$ & $\mathrm{p}<0,05$ \\
Bulanıklı (JTU) & 2,20 & 1,20 & 2,90 & 2,70 & $2,25 \pm 0,66$ & $\mathrm{p}<0,05$ \\
\hline
\end{tabular}

Tablo 39. Sarıkum Suyu analiz değerleri

\begin{tabular}{lllllll}
\hline Sarıkum Suyu (Tatvan) & Ilkbahar & Yaz & Sonbahar & Kış & Ortalama \pm Ss & $\begin{array}{l}\text { Önem } \\
\text { derecesi }\end{array}$ \\
\hline Çözünmüş oksijen (mg/L) & 7,84 & 7,16 & 7,65 & 7,90 & $7,64 \pm 0,29$ & $\mathrm{p}>0,05$ \\
pH (ppm) & 7,86 & 7,55 & 7,71 & 7,78 & $7,73 \pm 0,11$ & $\mathrm{p}>0,05$ \\
Nitrat (mg/L) & $<0,001$ & $<0,001$ & $<0,001$ & 4,11 & $1,03 \pm 2,06$ & $\mathrm{p}<0,05$ \\
Sicaklık ( $\left.{ }^{\circ} \mathrm{C}\right)$ & 10,45 & 11,24 & 10,22 & 10,11 & $10,51 \pm 0,44$ & $\mathrm{p}<0,05$ \\
Debi $(\mathrm{L} / \mathrm{sn})$ & 55,00 & 49,00 & 47,00 & 50,00 & $50,25 \pm 2,95$ & $\mathrm{p}<0,05$ \\
Bulanıklık (JTU) & 2,60 & 1,90 & 2,10 & 2,20 & $2,20 \pm 0,26$ & $\mathrm{p}<0,05$ \\
\hline
\end{tabular}

Tablo 40. Hersan Çayı analiz değerleri

\begin{tabular}{lllllll}
\hline Hersan Çayı (Merkez) & İlkbahar & Yaz & Sonbahar & Kiş & Ortalama \pm Ss & $\begin{array}{l}\text { Onem } \\
\text { derecesi }\end{array}$ \\
\hline Çözünmüş oksijen (mg/L) & 9,22 & 6,12 & 8,45 & 8,96 & $8,19 \pm 1,23$ & $\mathrm{p}<0,05$ \\
pH (ppm) & 5,90 & 5,84 & 6,02 & 6,10 & $5,97 \pm 0,10$ & $\mathrm{p}>0,05$ \\
Nitrat (mg/L) & $<0,001$ & $<0,001$ & $<0,001$ & 0,001 & $0,00 \pm 0,00$ & - \\
Sicaklık ( $\left.{ }^{\circ} \mathrm{C}\right)$ & 10,66 & 16,18 & 9,22 & 8,76 & $11,21 \pm 2,96$ & $\mathrm{p}<0,05$ \\
Debi (L/sn) & 110 & 20,00 & 50,00 & 95,00 & $68,75 \pm 35,77$ & $\mathrm{p}<0,05$ \\
Bulaniklık (JTU) & 12,80 & 4,60 & 5,10 & 5,50 & $7,00 \pm 3,36$ & $\mathrm{p}<0,05$ \\
\hline
\end{tabular}

Tablo 41. Aygır Gölü analiz değerleri

\begin{tabular}{lllllll}
\hline Aygır Gölü (Adilcevaz) & İlkbahar & Yaz & Sonbahar & Kış & Ortalama \pm Ss & $\begin{array}{l}\text { Önem } \\
\text { derecesi }\end{array}$ \\
\hline Çözünmüş oksijen (mg/L) & 8,12 & 7,66 & 7,98 & 8,23 & $8,00 \pm 0,21$ & $\mathrm{p}<0,05$ \\
pH (ppm) & 7,90 & 7,23 & 7,02 & 7,44 & $7,40 \pm 0,33$ & $\mathrm{p}<0,05$ \\
Nitrat (mg/L) & 0,001 & 2,64 & 0,001 & 0,001 & $0,66 \pm 1,32$ & $\mathrm{p}<0,05$ \\
Sicaklık ( $\left.{ }^{\circ} \mathrm{C}\right)$ & 11,20 & 23,01 & 14,10 & 9,38 & $14,42 \pm 5,24$ & $\mathrm{p}<0,05$ \\
Debi $(\mathrm{L} / \mathrm{sn})$ & - & - & - & - & - & - \\
Bulanıklık (JTU) & 3,00 & 1,10 & 2,40 & 1,60 & $2,03 \pm 0,73$ & $\mathrm{p}<0,05$ \\
\hline
\end{tabular}

Tablo 42. Nazik Gölü analiz değerleri

\begin{tabular}{lllllll}
\hline Nazik Gölü (Ahlat) & İlkbahar & Yaz & Sonbahar & Kiş & Ortalama \pm Ss & $\begin{array}{l}\text { Onem } \\
\text { derecesi }\end{array}$ \\
\hline Çözünmüş oksijen (mg/L) & 8,17 & 7,82 & 8,14 & 8,23 & $8,09 \pm 0,16$ & $\mathrm{p}<0,05$ \\
pH (ppm) & 6,79 & 7,20 & 7,26 & 7,11 & $7,09 \pm 0,18$ & $\mathrm{p}<0,05$ \\
Nitrat (mg/L) & 0,001 & 1,53 & 0,001 & 0,001 & $0,38 \pm 0,77$ & $\mathrm{p}<0,05$ \\
Sicaklık ( $\left.{ }^{\circ} \mathrm{C}\right)$ & 10,78 & 15,75 & 7,36 & 1,27 & $8,79 \pm 5,27$ & $\mathrm{p}<0,05$ \\
Debi (L/sn) & - & - & - & - & - & - \\
Bulankklik (JTU) & 4,10 & 2,50 & 3,40 & 3,30 & $3,33 \pm 0,57$ & $\mathrm{p}<0,05$ \\
\hline
\end{tabular}


Tablo 43. Van Gölü analiz değerleri

\begin{tabular}{lllllll}
\hline Van Gölü (Tatvan) & Ilkbahar & Yaz & Sonbahar & Kış & Ortalama \pm Ss & $\begin{array}{l}\text { Önem } \\
\text { derecesi }\end{array}$ \\
\hline Çözünmüş oksijen (mg/L) & 7,75 & 7,60 & 8,20 & 7,92 & $7,87 \pm 0,22$ & $\mathrm{p}<0,05$ \\
pH (ppm) & 9,75 & 9,92 & 9,88 & 9,49 & $9,76 \pm 0,17$ & $\mathrm{p}>0,05$ \\
Nitrat $(\mathrm{mg} / \mathrm{L})$ & 0,001 & 4,89 & 0,001 & 0,001 & $1,22 \pm 2,45$ & $\mathrm{p}<0,05$ \\
Sicaklik ( $\left.{ }^{\circ} \mathrm{C}\right)$ & 12,60 & 15,80 & 9,22 & 7,20 & $11,21 \pm 3,28$ & $\mathrm{p}<0,05$ \\
Debi $(\mathrm{L} / \mathrm{sn})$ & - & - & - & - & - & - \\
Bulanıklık (JTU) & 5,50 & 4,60 & 4,80 & 4,50 & $4,85 \pm 0,39$ & $\mathrm{p}<0,05$ \\
\hline
\end{tabular}

Bitlis ilindeki su kaynaklarının çözünmüş oksijen değerleri; ilkbaharda 5,10-9,63 mg/L, yazın 4,39-10,30 mg/L, sonbaharda 4,80-10,80 mg/L ve kışın 4,90-11,50 mg/L arasında değişmektedir. Su kaynaklarının yıl içerisindeki ortalama çözünmüş oksijen değerlerinin 4,86-9,25 mg/L arasında değişim gösterdiği tespit edilmiş̧ir. Mevcut su kaynaklarının pH değerleri; ilkbaharda 6,52-9,75 ppm, yazın 5,24-9,92 ppm, sonbaharda 5,78-9,88 ppm ve kışın 6,10-9,49 ppm arasında olup, yıl içerisindeki ortalama $\mathrm{pH}$ değerleri $6,27-9,76 \mathrm{ppm}$ arasında değişmektedir. Nitrat değerleri; ilkbaharda $0,00-9,60$ $\mathrm{mg} / \mathrm{L}$, yazın $0,00-37,30 \mathrm{mg} / \mathrm{L}$, sonbaharda $0,00-10,60 \mathrm{mg} / \mathrm{L}$ ve $\mathrm{k} ı s ̧ ı n ~ 0,00-21,97 \mathrm{mg} / \mathrm{L}$ arasında değişmektedir. Bu su kaynaklarının yıl içerisindeki ortalama nitrat değerlerinin ise $0,00-14,70 \mathrm{mg} / \mathrm{L}$ arasında değiştiği belirlenmiştir. Sicaklık değerleri; ilkbaharda $9,50-12,60{ }^{\circ} \mathrm{C}$, yazın $10,07-23,01{ }^{\circ} \mathrm{C}$, sonbaharda $9,22-14,00{ }^{\circ} \mathrm{C}$ ve kışın $1,27-10,97{ }^{\circ} \mathrm{C}$ arasında olup, yıl içerisindeki ortalama sıcaklık değerleri ise 9,51-14,42 ${ }^{\circ} \mathrm{C}$ arasında değişmektedir. Debi değerleri; ilkbaharda 11-530 L/sn, yazın 4-277 L/sn, sonbaharda 5-360 L/sn ve kışın 10,66-450 L/sn arasında değişmektedir. Su kaynaklarının yıl içerisindeki ortalama debi değerleri ise 6,75-426,3 L/sn arasında değişim göstermektedir. Bulanıklık değerleri; ilkbaharda 3,10-14,20 JTU, yazın 0,20-16,30 JTU, sonbaharda 0,60-11,40 JTU ve kışın 0,5013,80 JTU arasında olup, yıl içerisindeki ortalama bulanıklık değerleri 0,55-12,95 JTU arasında değişmektedir.

Entansif alabalık yetiştiriciliği için Tarım ve Orman Bakanlığ tarafından belirlenmiş olan su kalitesi kriterleri mevcuttur [30]. Bu kriterlere göre; suyun çözünmüş oksijen miktar1 9,2-11,5 mg/L, pH's1 6,5-8,0 ppm ve sıcaklığ $9-17{ }^{\circ} \mathrm{C}$ arasında olmalı, nitrat $100 \mathrm{mg} / \mathrm{L}$ 'den, bulanıklık ise 10 JTU'dan az olmalıdır. Belirtilen su kalitesi kriterlerine göre, Bitlis İlinde; ortalama çözünmüş oksijen değeri 9,2$11,5 \mathrm{mg} / \mathrm{L}$ arasında olan 3 adet, $\mathrm{pH}$ değeri 6,5-8,5 aralığında olan 32 adet, nitrat değeri $100 \mathrm{mg} / \mathrm{L}$ 'nin altında olan 37 adet, sicaklığ $19-17^{\circ} \mathrm{C}$ ' arasında olan 37 adet, debisi $100 \mathrm{~L} /$ sn' den fazla olan 19 adet ve bulanıklık değeri 10 JTU'dan az olan 30 adet su kaynağı bulunmaktadır.

\section{Sonuç ve Öneriler}

$\mathrm{Bu}$ çalışmada, Bitlis ilinin su ürünleri yetiştiriciliğindeki mevcut durumu ve su ürünleri yetiştiriciliği potansiyeli açığa çıkarılmıştır. Bu amaçla, mevcut 5 adet gökkuşağı alabalığı yetiştiricilik tesisine ve 37 adet su kaynağına yıl boyunca ve 3 aylık periyotlar halinde gidilmiş̧ir. İşletmelerdeki yetkili kişi ve çalışanlarla yüz yüze yapılan anket çalışmasıyla işletmelerin yapısal, biyolojik, teknik, sosyal ve ekonomik özellikleri hakkında veriler elde edilmiştir. Ayrıca, su kaynaklarının oksijen, pH, nitrat, sıcaklık, debi ve bulanıklık değerleri tespit edilmiştir.

Bölgedeki iş imkânlarının kısıtlı olması ve balıkçılığın katma değer sağlayacağı düşüncesi, bu ilde kültür balıkçılığına yönelişte etkili olmuştur. Tarihsel süreçte bölge halkının Van Gölü ile iç içe olması da balık ile üretici arasında doğal bir bağlantı kurmaktadır.

Bitlis ilindeki gökkuşağı alabalığı işletmelerinin arazideki konumları bölgenin coğrafik yapısıyla ve su kaynağına yakınlığıyla doğrudan ilişkilidir. Mevcut işletmelerin su kaynaklarına yakın olması, kuluçkahanelerin tesisin içinde bulunması ve ulaşım sorunlarının olmaması bunlar için önemli bir avantaj sağlamaktadır. Bununla birlikte, bütün işverenler bürokratik sorunlardan, yem maliyetinin çok yüksek olmasından ve işletmelerde görülen balık hastalıklarından yakınmaktadır. İşletmeler balık hastalıklarının önlenmesi ve tedavisine yönelik yeterli bilgiye sahip değildir. Balık hastalıkları konusunda uzmanlaşmış birimlerin desteğine ihtiyaç duyulmaktadır. Balık ölümlerinin yaşandığı veya yem ödeme vadelerinin kısa tutulduğu olumsuz durumlarda, işletmeler üretimi sürdürebilmek için banka kredilerine başvurmaktadır. Yemin temin edildiği merkezlerin işletmelere uzak oluşu nakliye giderlerini ve dolayısıyla üretim maliyetini artırmaktadır. İşletmelerinin giderleri; tesislerin büyüklüğüne, 
kullanılan yapı malzemesine, makine ve aletlere, yıllık üretim miktarına, personel sayısına, arazi yapısına, şehir ve girdi merkezlerine olan uzaklıklarına ve üretim periyodu içerisindeki balık ölümlerine bağlı olarak değişiklik göstermektedir. Bu işletmelerin önemli bir kısmının kapasite kullanım oranları düşük olup, projelendirilmiş üretim kapasitelerine ulaş1lamamıştır. Mevcut işletmeler genelde küçük aile tipi işletmeleridir. Bunların büyük bölümü maddi imkânsızlıklardan dolayı uygun olmayan şartlarda üretim yapmaktadır. Ayrıca işletmeler kalifiye elaman istihdam edemediklerinden, olması gereken üretim verimliliğine sahip değildir. Bu işletmeler doğrusal ve sürekli bir büyüme sağlamak yerine, daha çok mevcut kapasitelerini koruma eğilimindedir. Bunun en önemli sebebi yüksek maliyetler ve ekonomik sıkıntılardır. Bazı işletmeler için üretimde kullanılan suyun debisinin sınırlı olması da büyümeye engel olan faktörler arasındadır. İşletmelerin örgütlü olmadığı, karşılaşılan sorunlarla tek başlarına mücadele ettikleri, bu nedenle çözüm noktasında başarısız oldukları tespit edilmiştir.

$\mathrm{Bu}$ işletmeler aynı zamanda lokantaya da sahiptir. Balık iç organları ve yemek artıkları kesinlikle balık beslemesinde kullanılmamalıdır. İşletmelerde çalışan işçilere bu konuda gerekli uyarı ve bilgilendirmenin yapılması balık ve insan sağlığı açısından önem taşımaktadır.

Balıkların üretilmesi veya pazarlanmasında işletmelerin sıkıntıları yoktur. Ancak yüksek yem maliyeti nedeniyle balıkların büyütülmesinde sıkıntı yaşanmaktadır. Balıklar piyasaya perakende veya toptan peşin ödeme yoluyla satılmaktadır. Ayrıca işletmelere ait lokantalarda da tüketilmektedir.

Bitlis ilindeki gökkuşağı alabalığı işletmelerinde görülen önemli sorunlardan bir diğeri ise, çalışanların sosyo-ekonomik şartlarının istenilen düzeyde olmamasıdır. İşletmelerin üretimdeki payının genişletilebilmesi; çalışanların sosyal haklarının yeterince sağlanması, onlara değer verilerek bilgi ve donanımlarının artırılması ile mümkün olacaktır. Bunun yanı sıra, bu işletmelerde mutlaka su ürünleri mühendisi ve su ürünleri teknikeri çalıştırılarak teknik bilgi eksikliğinin giderilmesi sağlanmalıdır. Karşılaşılan problemlerin çoğu bir uzman yardımı ile çözülebilecek niteliktedir.

Ayrıca, mevcut gökkuşağı alabalığı işletmelerinin düzenli veri kayıt alt yapısının olmaması önemli bir eksiklik olarak görülmüştür. Bu konuda üreticilere gerekli teknik destek sağlanarak veri kayıt sistemi oluşturma şekilleri öğretilmiştir. Veri kayıt sistemi kullanımının sürekli hale getirilmesi durumunda fayda sağlayacağ belirtilmiştir. İşletmelerde oturtulmaya çalışılan bu veri kayıt sistem mantığı, genellikle yüksek kapasiteli yetiştiricilik şirketlerinde kullanılmakta olup, Bitlis ilindeki mevcut işletmelerin bu sisteme ağırlık vererek kendilerini geliştirmeleri; ekonomik seviyelerinin artmasına ve daha büyük işletmeler haline gelmelerine katkı sağlayacaktır.

Bitlis ilinde ortalama çözünmüş oksijen değeri 9,2-11,5 mg/L arasında olan 3 adet, $\mathrm{pH}$ değeri 6,5-8,5 aralığında olan 32 adet, nitrat değeri $100 \mathrm{mg} / \mathrm{L}$ 'nin altında olan 37 adet, sıcaklığı $9-17{ }^{\circ} \mathrm{C}$ ' arasında olan 37 adet, debisi $100 \mathrm{~L} / \mathrm{sn}$ 'den fazla olan 19 adet ve bulanıklık değeri 10 JTU'dan az olan balık yetiştiriciliğine uygun 30 adet potansiyel su kaynağı bulunmaktadır.

Mevcut su kaynaklarının analizi sonucu elde edilen veriler; yer altı sularının oksijen miktarının genellikle düşük olduğunu göstermektedir. Bunun dışındaki su kaynaklarına ait veriler genellikle kabul edilebilir değerler arasındadır. Bazı su kaynaklarındaki oksijen düşüklügünün ise suyun havalandırılması ile giderilebileceği değerlendirilmektedir. Yer altı suları tarımsal faaliyetlerde daha çok sulama amacıyla kullanılmaktadır. Çiftçilerin sulama ile birlikte su ürünleri üretimini de alternatif olarak değerlendirmesi önerilmektedir. Özellikle düşük debilerde olduğu görülen yer altı sularının küçük kapasiteli alabalık kuluçkahaneleri için uygun olabileceği düşünülmektedir.

Çay ve dere suları ise çözünmüş oksijen, $\mathrm{pH}$, nitrat, sıcaklık ve debi miktarı açısında optimal şartları sağlamaktadır. Bununla birlikte, özellikle ilkbahar aylarında karların erimesi veya yağmur yağışları sonucu toprak aşınması nedeniyle suyun bulanıklı̆̆ artmaktadır. Bu nedenle çay ve dere suları balık yetiştiriciliğinde yılın 12 ayı süresince kullanılamaz. Bulanık suların uzun süreli tesiste kullanılması; yem miktarı ve yemleme sıklığının düşürülmesine, balıklarda büyümenin gerilemesine, solungaç hastalıklarına, bağışıklık sisteminin zayıflamasına ve sağlık problemlerine yol açabileceği ve balık ölümlerinin yaşanabileceği gözden kaçırılmamalıdır.

Bitlis ilinde kafeslerde gökkuşağı alabalığı yetiştiriciliği yapan sadece bir işletme (Aygır Gölü'nde) mevcuttur. Suların 1sınması; bu işletmede balık stok miktarının azaltılmasına, üretim kapasitesinin düşük seviyelerde tutulmasına sebep olmaktadır. Ayrıca işletmenin bulunduğu gölün sulama suyu temininde yoğun olarak kullanılması balık üretiminin gelişimini olumsuz etkilemektedir. Diğer taraftan bilinçli üretim modelinin uygulanması, suyun diğer fiziksel ve kimyasal özelliklerinin iyi olması sağlıklı bir üretimin gerçekleşmesine imkan sağlayabilir.

Nazik Gölü balık avcılığı yönünden verimli olarak kullanılmakta ancak, balık yetiştiriciliğinde 
değerlendirilmemektedir. Bunun en önemli nedeni, soğuk geçen kış aylarında göl yüzeyinin tamamen donmasıdır. Buna rağmen balık yetiştiriciliği amacıyla mevsimlik olarak değerlendirilebilir.

Bitlis ilindeki mevcut su kaynaklarında yapılan örneklemeler neticesinde, tarımsal kirliliğe bağlı olarak değişen nitrat değerlerinin balık yetiştiriciliği açısından genel olarak herhangi bir sorun oluşturmadığı tespit edilmiştir. Bunun yanı sıra, il sınırları içerisinde su kaynaklarının kirlenmesine sebebiyet verecek büyük ölçekli herhangi bir sanayi kuruluşu, fabrika, maden işletmesi vb. bulunmadığından, potansiyel su kaynaklarının su ürünleri üretiminde kullanılmasında herhangi bir sakınca görülmemektedir.

Ayrıca, saha çalışmaları sırasında rastlanan ve ilin Tatvan ve Güroymak ilçe sınırları içerisinde bulunan jeotermal su kaynaklarının da tilapia vb. balıkların yetiştiriciliğinde kullanılabileceği öngörülmektedir.

Su ürünleri üretimine olan ihtiyaç her geçen yıl artarken ülkemizdeki mevcut su kaynaklarının yetiştiricilikte kullanım kapasiteleri de dolmaktadır. Bu nedenle, ilerleyen yıllarda Bitlis ilindeki potansiyel su kaynaklarının üretimde kullanılması için girişimcilerin teşebbüslerde bulunabileceği düşünülmektedir. Ayrıca, güvenlik açısından tereddütlerin tamamen ortadan kalkması durumunda, özellikle Hizan ilçesindeki su kaynağı potansiyeli verimli bir şekilde balık üretiminde kullanılabilir.

Sonuç olarak, Bitlis ilindeki kültür balıkçılığının nitelik ve niceliğinin arttırılabilmesi, üretimde optimizasyonun sağlanabilmesi, geleceğe yönelik projeksiyonların yapılabilmesi, su ürünleri üretiminin il, bölge ve ülke ekonomisine olan katkılarının arttırılabilmesi için; mevcut işletmeler yapısal, teknik ve ekonomik yönden geliştirilmelidir. Bölgede kültür balıkçılığı verileri istenen düzeyde olmasa da devlet desteğinin her geçen yıl artması ve çeşitlilik kazanması, gelişen teknoloji ve potansiyel su kaynaklarının değerlendirmeye alınmasıyla birlikte kültür balıkçılığına olan ilgi de her geçen gün artacaktır.

\section{Teșekkür}

$\mathrm{Bu}$ çalı̧̧ma, birinci yazarın yüksek lisans tezinden özetlenmiştir. Yazarlar, çalışmayı maddi olarak destekleyen Fırat Üniversitesi Bilimsel Araştırma Projeleri (FÜBAP) Koordinasyon Birimine (Protokol No: SÜF.18.08), kurumsal bazı verilerin sağlanması ve yayınlanmasında herhangi bir sakınca görneyen Bitlis İl Tarım ve Orman Müdürlüğüne teşekkür ederler.

\section{Yazarların Katkısı}

Yazarların makaleye katkısı eşittir.

\section{Çıkar Çatışması Beyanı}

Yazarlar arasında herhangi bir çıkar çatışması bulunmamaktadır.

\section{Araştırma ve Yayın Etiği Beyanı}

Yapılan çalışmada, araştırma ve yayın etiğine uyulmuştur

\section{Kaynaklar}

[1] Seyis T. 2003. Türkiye'de Su Ürünleri Pazarlama Sistemi ve Balık Hallerinin Fonksiyonel Durumu. Doktora Tezi, Ege Üniversitesi, Fen Bilimleri Enstitüsü, 55 s., İzmir.

[2] Köprücü K. 2007. Türkiye Su Ürünleri Üretiminin Durumu ve Değerlendirilmesi. Türk Tarım Dergisi, 178: 22-28.

[3] FAO (Food and Agriculture Organization), 2016. World Review of Fisheries and Aquaculture. T.C. Tarımsal Ekonomi ve Politika Geliştirme Enstitüsü, Ankara.

[4] Aydın O., Sayılı M. 2009. Samsun İlinde Alabalık İşletmelerinin Yapısal ve Ekonomik Analizi. GOÜ, Ziraat Fakültesi Dergisi, 26 (2): 97-107.

[5] TÜİK (Türkiye İstatistik Kurumu), 2018. Su Ürünleri İstatistikleri, Ankara. 
[6] Yıldız M., Şener E. 2003. Karadeniz Bölgesi'ndeki Gökkuşağı Alabalığı (Oncorhynchus mykiss) ve Deniz Levreği (Dicentrarchus labrax) Yetiştiriciliği Yapan İşletmelerin Yapısal Analizi ve Biyo-Teknolojik Özellikleri. İstanbul Üniversitesi Veteriner Fakültesi Dergisi, 29 (2): 241-252.

[7] Akbulut B., Kurtoğlu İ.Z., Üstündağ E., Aksungur M. 2009. Karadeniz Bölgesinde Balık Yetiştiriciliğinin Tarihsel Gelişimi ve Gelecek Projeksiyonu. Journal of Fisheriessciences.com, 3 (2): 76-85.

[8] URL-1, 2019. https://bitlis.tarimorman.gov.tr/Menu/17/Ilimiz-Hakkinda-Genel-Bilgiler (Erişim Tarihi: 19.04.2019).

[9] Anonim, 2017. Bitlis Gıda Tarım ve Hayvancılık İl Müdürlüğü Kayıtları.

[10] URL-2, 2019. https://www.google.com/search?q=bitlis+fiziki+haritas\%C4\%B1\&tbm=isch\& source $=$ iu\&ictx=1\# (Erişim Tarihi: 24.09.2019).

[11] Emre Y., Diler İ., Sevgili H., Oskay D.A., Sayı C. 2007. Akdeniz Bölgesi'ndeki Alabalık İşletmelerinin Yapısal Özelliklerinin İncelenmesi (2000-2003). Türk Sucul Yaşam Dergisi, 3-5 (5-8): 476-489.

[12] Karataş M., Sayılı M., Koç B. 2008. Sivas İli Gökkuşağı Alabalığı İşletmelerinin Yapısal ve Ekonomik Analizi. Biyoloji Bilimleri Araştırma Dergisi (BİBAD), 1 (2): 55-61.

[13] Yıldız M., Doğan K., Şener E. 2008. Marmara Bölgesi Gökkuşağı Alabalığı (Oncorhyncus mykiss) İşletmelerin Yapısal, Teknolojik ve Verimlilik Analizleri. İstanbul Üniversitesi Su Ürünleri Dergisi, 23: 1-16.

[14] Yüksel O. 2010. Burdur İli Gökkuşağı Alabalığı İşletmelerinin Yetiştiricilik ve Yapısal Durumlarının Survey Çalışması ile Araştırılması. Yüksek Lisans Tezi, Süleyman Demirel Üniversitesi, Fen Bilimleri Enstitüsü, Isparta.

[15] Emre Y., Sayın C., Kiştin F., Emre N., Karaman S. 2011. Alabalık (Oncorhynchus mykiss) Kafes Yetiştiriciliğinin Mevcut Durumuna Yönelik Bazı Değerlendirmeler. Biyoloji Bilimleri Araştırma Dergisi (BİBAD), 4 (1): 119-127.

[16] Gümüş E., Şahin N.M., İkiz R., Yılmaz S. 2013. Antalya İlindeki Gökkuşağı Alabalığ1 (Oncorhynchus mykiss) İşletmelerinde Çalışanların Sosyo-Ekonomik Yapılarının İncelenmesi. Ege Üniversitesi Su Ürünleri Dergisi, 30 (4): 161-166.

[17] Yeşilayer, N., Gören, H.M., 2013. Tokat'ta Alabalık Yetiştiriciliği Yapan Karasal İşletmelerin Yapısal ve Biyo-Teknik Analizi. Gaziosmanpaşa Üniversitesi Ziraat Fakültesi Dergisi, 30 (1): 41 51.

[18] Kocaman E., Sayılı M. 2014. Gümüşhane ilinde gökkuşağı alabalık işletmelerinin ekonomik analizi. Anadolu Tarım Bilimleri Dergisi, 29 (1): 36-45.

[19] Preisendorfer R.W. 1986. Secchi Disc Science: Visual Optics of Natural Waters. Limnology and Oceonography, 31 (5): 909-926.

[20] Yücesoy C., Onur F., Özkan S. 1989. Sularda Nitrat Tayininde Kullanılan Spektrofotometrik Yöntemlerin Karşılaştırılması. FABAD Farmasötik Bilimler Dergisi, 14: 216-223.

[21] Y1lmaz C. 2011. Alabalık Yetiştiriciliği. Elazığ İl Tarım Müdürlüğü, 2. Baskı, Elazığ.

[22] Rad F., Köksal G. 2001. Türkiye' deki Gökkuşağı Alabalığı (Oncorhynchus mykiss) İşletmelerinin Yapısal ve Biyo-Teknik Analizi. Turkish Journal of Veterinary and Animal, 25: 567-575.

[23] Doğan K., Yıldız M. 2008. Marmara Bölgesi Gökkuş̧ăı Alabalığı (Oncorhynchus mykiss) İşletmelerinde Çalışanların Sosyo-Ekonomik Analizi. İstanbul Üniversitesi Su Ürünleri Dergisi, 23: 17-27.

[24] Kocaman E.M., Aydın A., Ayık Ö. 2002. Erzurum'da Faaliyet Gösteren Alabalık İşletmelerinin Yapısal ve Ekonomik Analizi. EU Journal of Fisheries \& AquaticSciences, 19 (3-4): 319-327.

[25] Adigüzel F., Akay M. 2005. Tokat İlinde Gökkuşağı Alabalık İşletmelerinin Ekonomik Analizi. GOÜ Ziraat Fakültesi Dergisi, 22 (2): 31-40.

[26] Güneş E., Köprücü K. 2019. Kahramanmaraş’taki Gökkuşağı Alabalığı (Oncorhynchus mykiss) Kuluçkahanelerinin Yapısal, Biyolojik ve Teknik Yönlerden Araştırılması. Acta Aquatica Turcica, 15 (1): 68-79.

[27] Karabulut M., Köprücü K. 2019. Malatya'daki Gökkuşağı Alabalığı (Oncorhynchus mykiss) Kuluçkahanelerinin Yapısal ve Biyolojik Yönden İncelenmesi. BEÜ Fen Bilimleri Dergisi, 8 (1): $1-10$. 
[28] Gümüş E., Şahin N.M. 2015. Antalya İlindeki Gökkuşağı Alabalığı (Oncorhynchus mykiss) İşletmelerinin Kuluçka Faaliyetlerinin Analizi. Biyoloji Bilimleri Araştırma Dergisi (BİBAD), 8 (2): 44-50.

[29] Üstündağ E., Aksungur M., Dal A., Yılmaz C. 2000. Karadeniz Bölgesi'nde Su Ürünleri Yetiştiriciliği Yapan İşletmelerin Yapısal Analizi ve Verimliliğinin Belirlenmesi, Proje Sonuç Raporu, Su Ürünleri Merkez Araştırma Enstitüsü, Trabzon.

[30] URL-6, 2019. ttps://www.tarimorman.gov.tr/BSGM/Belgeler/Icerikler/Su\%20\%C3\%9Cr\%C3\% BCnleri\%20Yeti\%C5\%9Ftiricili\%C4\%9Fi/2-20Alabal\%C4\%B1k\%20Yeti\%C5\%9Ftiricili\%C4 $\% 9 \mathrm{Fi} \% 20 \% \mathrm{C} 4 \% \mathrm{~B} 0 \% \mathrm{C} 3 \% \mathrm{~A} 7 \mathrm{in} \% 20 \mathrm{Su} \% 20 \mathrm{Kalite} \% 20 \mathrm{Kriterleri.pdf(Erişim} \mathrm{Tarihi:19.04.2019).}$ 